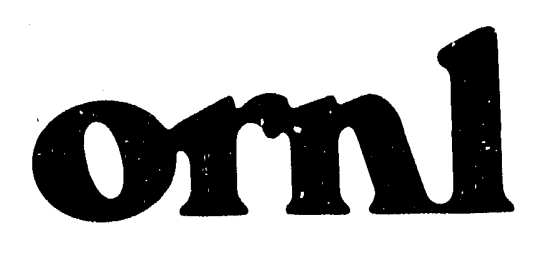

\section{OAK RIDGE NATIONAL LABORATORY}

MARTIN MARLETHA

\section{ORNL/RASA-91/8}

FEB 261992

\title{
Results of the Radiological Survey at the New Betatron Building, Granite City Steel Facility, Granite City, Illinois (GSG002)
}

\author{
M. E. Murray \\ M. S. Uziel
}


This report has been reproduced directly from the best available copy.

Avallable to DOE and DOE contractors from the Office of Scientific and Technical Information, P.O. Box 62, Oak Ridge, TN 37831; prices available from (615) 576-8401, FTS 626-8401.

Avallable to the public from the National Technical Information Service, U.S. Department of Commerce, 5285 Port Royal Rd., Springtield, VA 22161.

This report was prepared as an account of work sponsored by an agency of the United States Government. Neither the United States Government nor any agency thereof, nor any of their employees, makes any warranty, express or implled, or assumes any legal liability or responsibility for the accuracy, completeness, or usefulness of any information, apparatus, product, or process disclosed, or represents that its use would not infringe privately owned rights. Reference herein to any specific commercial product, process, or service by trade name, trademark, manufacturer, or otherwise, does not necessarily constitute or imply its endorsement, recommendation, or favoring by the United States Government or any agency thereof. The views and opinions of authors expressed herein do not necessarily state or reflect those of the United States Government or any agency thereof. 


\title{
HEALTH AND SAFETY RESEARCH DIVISION
}

\section{Environmental Restoration and Waste Management Non-Defense Programs} (Activity No. EX 202001 0; ADS3170000)

\section{Results of the Radiological Survey at the New Betatron Building, Granite City Steel Facility, Granite City, Illinois (GSG002)}

\author{
M. E. Murray and M. S. Uziel
}

Date Issued - January 1992

\section{Investigation Team}

R. E. Swaja - Measurement Applications and Development Manager W. D. Cottrell - Project Director

M. E. Murray - Field Survey Supervisor

\author{
Survey Team Members \\ R. L. Coleman \\ D. E. Rice \\ W. H. Shinpaugh* \\ ${ }^{*}$ D. R. Stone, Associates
}

Work performed by the MEASUREMENT APPLICATIONS AND DEVELOPMENT GROUP

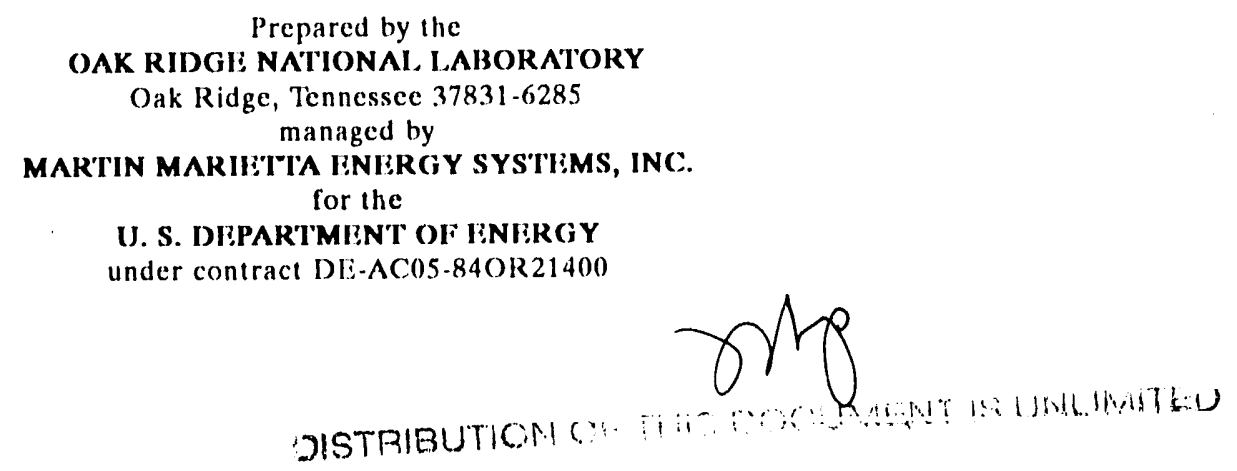




\section{CONTENTS}

LIST OF FIGURES $\ldots \ldots \ldots \ldots \ldots \ldots \ldots \ldots \ldots \ldots \ldots \ldots \ldots \ldots$

LIST OF TABLES $\ldots \ldots \ldots \ldots \ldots \ldots \ldots \ldots \ldots \ldots \ldots \ldots \ldots \ldots \ldots \ldots \ldots \ldots$

ACKNOWLEDGMENTS $\ldots \ldots \ldots \ldots \ldots \ldots \ldots \ldots \ldots \ldots \ldots \ldots \ldots \ldots \ldots \ldots$

ABSTRACT $\ldots \ldots \ldots \ldots \ldots \ldots \ldots \ldots \ldots \ldots \ldots \ldots \ldots \ldots \ldots \ldots \ldots \ldots$

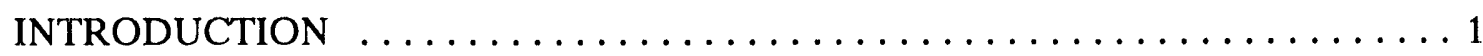

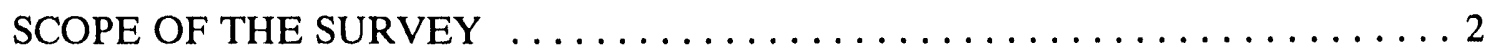

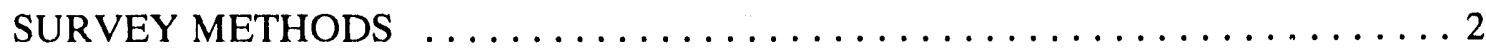

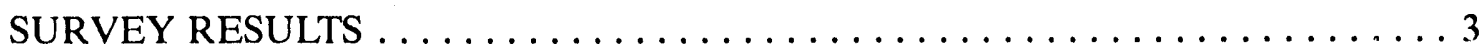

GAMMA EXPOSURE RATE MEASUREMENTS $\ldots \ldots \ldots \ldots \ldots \ldots \ldots \ldots 3$

DIRECT AND REMOVABLE ALPHA RADIOACTIVITY LEVELS . . . . . 3

DIRECT AND REMOVABLE BETA-GAMMA RADIOACTIVITY

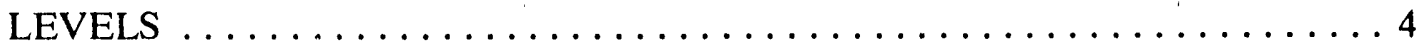

SOIL AND SHIELD-WALL FILL MATERIAL SAMPLES $\ldots \ldots \ldots \ldots \ldots \ldots 4$

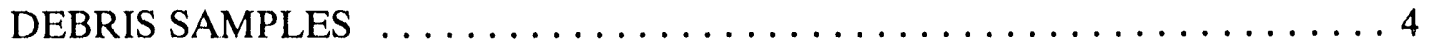

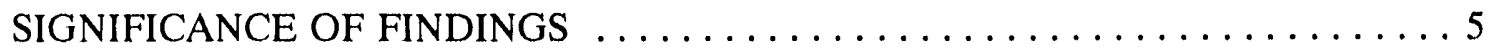

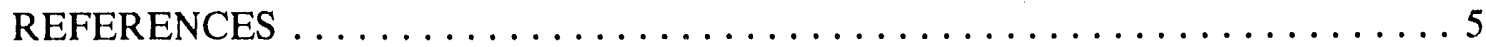




\section{LIST OF FIGURES}

1 General location of Granite City, Illinois $\ldots \ldots \ldots \ldots \ldots \ldots \ldots \ldots$

2 General location of the South Plant facility, Granite City Steel Division, Granite City, Illinois $\ldots \ldots \ldots \ldots \ldots \ldots$

3 Diagram of the New Betatron Building, Granite City Steel

facility, Granite City, Illinois. . . . . . . . . . . . . . . . . . 8

4 View looking north northwest at the New Betatron Building,

Granite City Steel facility, Granite City, Illinois . . . . . . . . . . . . . . 9

5 View looking east at entrance to the New Betatron Building,

Granite City Steel facility, Granite City, Illinois . . . . . . . . . . . . . 9

6 Vicw looking south at entrance to interior rooms $\ldots \ldots \ldots \ldots \ldots \ldots \ldots$

7 View looking northeast inside New Betatron Building with main entrance at left of photograph $\ldots \ldots \ldots \ldots \ldots \ldots \ldots \ldots$

8 View of northwest wall in the New Betatron Building, Granite City Steel facility $\ldots \ldots \ldots \ldots \ldots \ldots \ldots \ldots \ldots \ldots \ldots \ldots$

9 View looking southwest inside the New Betatron Building, Granite City Stecl facility . . . . . . . . . . . . . . . . . . 12

10 Vicw looking at southeast wall from the railroad track $\ldots \ldots \ldots \ldots \ldots \ldots 12$

11 View looking west at scissors lift used to access top of shicld wall and upper-level horizontal beams $\ldots \ldots \ldots \ldots \ldots \ldots \ldots$

12 Vicw of top of shield wall from scissors lift $\ldots \ldots \ldots \ldots \ldots \ldots \ldots \ldots$

13 View on top of shick wall looking southeast $\ldots \ldots \ldots \ldots \ldots \ldots \ldots \ldots$

14 View looking south at vent 4 on flat roof above second

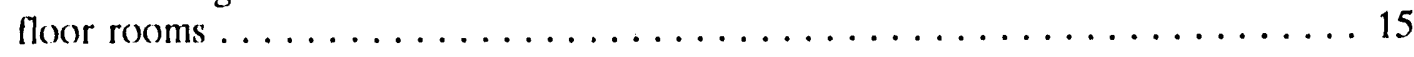

15 View on top of New Betatron Building looking west at

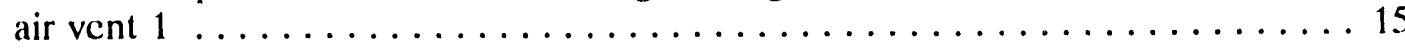


16 Gamma exposure rates at the New Betatron Building, Granite City Steel facility, Granite City, Illinois ................. 16

17 Sample locations and results of the surface gamma scan on the roof at the New Betatron Building $\ldots \ldots \ldots \ldots \ldots \ldots \ldots \ldots \ldots \ldots$

18 Sample locations and results of alpha $(\alpha)$, beta-gamma $(\beta-\gamma)$, and gamma $(\gamma)$ measurements at selected locations inside the New Betatron Building 


\section{LIST OF TABLES}

1 Applicable guidelines for protection against radiation $\ldots \ldots \ldots \ldots \ldots \ldots$

2 Background radiation levels for the Granite City, Illinois, area $\ldots \ldots \ldots \ldots \ldots 21$

3 Alpha and beta-gamma measurements at the New

Betatron Building, Granite City Siecl facility,

1417 State Street, Granite City, Illinois . . . . . . . . . . . . . . 22

4 Concentrations of radionuclides in soil and debris samples collected at the New Betatron Building, Granite City Steel

facility, 1417 State Strect, Granite City, Illinois 


\section{ACKNOWLEDGMENTS}

This project was sponsored by the Office of Environmental Restoration, U.S. Department of Energy, under contract DE-AC05-84OR21400 with Martin Marietta Energy Systems, Inc. The authors wish to acknowledge the contributions of R. F. Carrier, W. D. Cottrell, D. A. Roberts, and J. K. Williams of the Measurement Applications and Development Group and W. A. Williams of the U.S. Department of Energy for participation in the analyses, editing, and reporting of data for this survey. 


\begin{abstract}
At the request of the U.S. Department of Energy (DOE), a team from Oak Ridge National Laboratory conducted a radiological survey at the New Betatron Building, located in the South Plant facility of Granite City Steel Division, 1417 State Street, Granite City, Illinois. The survey was performed in August 1991. The purpose of the survey was to determine whether the property was contaminated with radioactive residues, principally ${ }^{238} \mathrm{U}$, as a result of work done for the Atomic Energy Commission (AEC) from 1958 to 1966. The survey included a surface gamma scan of the ground surface outdoors near the building, the floor and walls in all accessible areas inside the building, and the roof; measurement of betagamma dose rates, alpha radiation levels, and removable alpha and beta-gamma activity levels at selected locations inside the building and on the roof; and radionuclide analysis of outdoor soil samples and indoor samples of shield-wall fill material and debris.

Analysis of soil, shield-wall fill material, debris, and smear samples showed no residual ${ }^{238} \mathrm{U}$ attributable to former AEC-supported operations at this site. None of the indoor or outdoor gamma exposure rate measurements were elevated above DOE guidelines. The slight elevations in gamma levels found outdoors and on the roof over the shield wall are typical of naturally occurring radioactive substances present in coal ash and cinders in the fill material surrounding the building and in concrete and cinders used in construction of the shicld wall. The slightly elevated gamma levels measured at soil sampling locations can be attributed to the presence of naturally occurring radionuclides. In all samples, ${ }^{226} \mathrm{Ra}$ and ${ }^{238} \mathrm{U}$ appeared to be in equilibrium, indicating that these radionuclides were of natural origin and not derived from former AEC activities at this site.
\end{abstract}




\section{Results of the Radiological Survey at the New Betatron Building, Granite City Steel Facility, Granite City, Illinois (GSG002)*}

\section{INTRODUCTION}

During the late 1950s and early 1960s, the General Steel Castings Corporation was the custodian of a government-owned betatron used to X-ray uranium ingots for the Atomic Energy Commission (AEC) under purchase orders issued by Mallinckrodt Chemical Works. The facility used for this purpose is located at 1417 State Street in southwest Granite City, Illinois, northeast of St. Louis, Missouri, cast of the Mississippi River (Fig. 1). The site is now part of the South Plant facility (Fig. 2) of Granite City Stecl Division, a subsidiary of National Steel Corporation.

Purchase orders were issued by the Uranium Division, Mallinckrodt Chemical Works, from February 1958 through June 1966, first to General Steel Castings Corporation and later (July 14, 1961 and after) to General Stecl Industries, Inc., at the same address. The purchase orders indicate that General Steel Castings furnished the film and film developing services and suggest that Mallinckrodt personnel may have handled the uranium metal and operated the betatron equipment used to X-ray the metal. The purchase orders do not specify actual periods of operation or the quantity and configuration of the metal X-rayed. There are indications, however, that the facility was used on an "as required" basis, and the metal was in the form of ingots 18 to $20 \mathrm{in}$. in diameter, approximately $18 \mathrm{in.}$ long, and weighing up to $3000 \mathrm{lb}^{1}$

It is the policy of the U.S. Department of Energy (DOE) to verify that radiological conditions at such sites or facilities, comply with current DOE guidelines. ${ }^{2}$ If they are found to deviate to any significant degree from those guidelines, remedial action may be implemented to correct the unacceptable condition. Furthermore, guidelines for using such sites without radiological restrictions have become more stringent as research on the effects of low-level radiation has progressed.

In March 1989, the Oak Ridge National Laboratory (ORNL) conducted a preliminary survey at the request of DOE to determine if this site should be included for further assessment in the Formerly Utilized Sites Remedial Action Program (FUSRAP). At that time the Betatron Building was examined. The building, its roof, and the area surrounding it were founc to be generally free of residual radiological material originating from former AEC-sponsored activities. Some residual radioactive material was found in and around a vacuum eleaner and in scattered spots inside the building, but these were very localized and

\footnotetext{
*The survey was performed by members of the Measurement Applications and Development Group of the Health and Safety Research Division at Oak Qidge National I aboratory under DOE contract BE.ACOS$840 R 21400$.
} 
limited in extent, rendering it highly unlikely that an individual working in or frequenting the area would receive a significant radiation exposure..$^{3}$

Recent information has indicated that another building at this site, the New Betatron Building, may have been used for X-ray studies on uranium produced for DOE's predecessor, the AEC. At the request of DOE, the Measurement Applications and Development Group, ORNL, conducted a radiological survey of the New Betatron Building (Fig. 3) in August 1991. Results of that survey are presented in this report. The building was empty and idle at the time of the survey, but future plans include leasing the building for storage purposes.

\section{SCOPE OF THE SURVEY}

The radiological survey included: (1) a surface gamma scan of the ground surface outdoors near the building, the floor and walls in all accessible areas inside the building, and the roof; (2) measurement of beta-gamma dose rates and alpha radiation levels in selected locations inside the building and on the roof; (3) measurement of removable alpha and beta-gamma activity levels at 7 locations inside the building and 13 locations on the roof; (4) collection and radionuclide analysis of 3 outdoor soil samples, 2 samples of shield-wall fill material, and 2 indoor debris samples.

\section{SURVEY METHODS}

A comprehensive description of the survey methods and instrumentation used in this survey is given in Procedures Manual for the ORNL Radiological Survey Activities (RASA) Program, ORNL/TM-8600 (April 1987). ${ }^{4}$

Using a Nal scintillation probe connected to a Victoreen ratemeter, surface gamma levels were recorded for accessible areas of the floor and walls inside the building and outdoor areas near the building and on the roof. The detector was held approximately 2 in. above the floor/ground/roof surface, and measurements were recorded and then converted to $\mu \mathrm{R} / \mathrm{h}$. Using a Geiger-Mueller pancake detector, beta-gamma levels were recorded and then converted to $\mathrm{mrad} / \mathrm{h}$. Alpha levels were measured at selected locations with an ORNL alpha meter connected to a $\mathrm{ZnS}$ scintillation probe, and then converted to $\mathrm{dpm} / 100 \mathrm{~cm}^{2}$.

Smears were obtained from selected surfaces inside the building and on the roof to establish removable alpha and beta-gamma activity levels. Soil samples collected outdoors to depths of $15 \mathrm{~cm}$ and shield-wall* fill material and debris collected inside the building were analyzed for ${ }^{210} \mathrm{~Pb},{ }^{226} \mathrm{Ra},{ }^{232} \mathrm{Th},{ }^{238} \mathrm{U}$, and ${ }^{235} \mathrm{U}$.

\footnotetext{
*'The 10 -ft-thick shicld wall consisted of outer layers of concrete filled with a granular cinder-like material.
} 


\section{SURVEY RESULTS}

DOE guidelines are summarized in Table 1. Typical background radiation levels for the Granite City, Illinois, area are presented in Table 2. These data are provided for comparison with survey results presented in this section. All direct measurement results presented in this report are gross readings; background radiation levels have not been subtracted. Similarly, background concentrations have not been subtracted frum radionuclide concentrations measured in soil and debris samples. Removable radioactivity levels (smears) are reported as net disintegrations per minute $(\mathrm{dpm})$ with background subtracted.

Current photographs of the site are shown in Figs. 4-15.

\section{GAMMA EXPOSURE RATE MEASUREMENTS}

Results of gamma exposure rate measurements at the New Betatron Building are shown in Figs. 16 and 17. Outdoor gamma exposure rates near the building generally ranged from 8 to $17 \mu \mathrm{R} / \mathrm{h}$. Surface gamma levels at soil sampling locations measured 17,19 , and $21 \mu \mathrm{R} / \mathrm{h}$. Indoor rates ranged from 6 to $11 \mu \mathrm{R} / \mathrm{h}$ except in the area on top of the filled shicld wall where gamma levels reached $22 \mu \mathrm{R} / \mathrm{h}$ (Fig. 16). Gamma exposure rates on the roof were generally around $6 \mu \mathrm{R} / \mathrm{h}$, but roof areas directly over the filled shield wall ranged from 8 to 12 $\mu \mathrm{R} / \mathrm{h}$ (Fig. 17). Most gamma levels were near typical background levels of 7 to $11 \mu \mathrm{R} / \mathrm{h}$ in the Granite City area (Table 2). The slight elevations in ouldoor gamma levels are probably due to naturally occurring radioactive substances present in coal ash and cinders present in the fill material surrounding the building. The slight elevations in gamma levels on the roof and on the shield wall can be attributed to naturally occurring radioactive substances present in concrete, cinders, and other such materials used in construction of the shield wall. All exposure rates were below the DOE indoor guideline of $20 \mu \mathrm{R} / \mathrm{h}$ above background (Table 1).

\section{DIRECT AND REMOVABLE ALPHA RADIOACTIVITY LEVELS}

Direct alpha activity was measured at 13 locations on the roof and 9 locations inside the building. Locations of the roof measurements are shown on Fig. 17 and results are given in Table 3 (T2-T8 and T16-T21). Directly measured alpha activity on the roof ranged from $<25^{*}$ to $320 \mathrm{dpm} / 100 \mathrm{~cm}^{2}$, well below the applicable guideline for uranium (Table 1). Locations of indoor alpha activity measurements are shown on Fig. 18. Results of seven measurements are given in Table 3 (T9-T15) and two additional measurements are shown on Fig. 18. Directly measured alpha activity levels indoors ranged from $<25$ (Table 3 ) to $49 \mathrm{dpm} / 100 \mathrm{~cm}^{2}$ (Fig. 18), well below the applicable guideline for uranium (Table 1).

\footnotetext{
*'The instrument-specific minimum detectable activities (MDAs) for directly measured and removable alpha radiation levels are 25 and $10 \mathrm{dpm} / 100 \mathrm{~cm}^{2}$, respectively. For directly measured and removable beta-gamma radiation levels the MIAs are $0.01 \mathrm{mrad} / \mathrm{h}$ and $200 \mathrm{dpm} / 100 \mathrm{~cm}^{2}$, respectively.
} 
After recording the direct alpha activity levels, 13 locations on the roof and 7 locations inside the building were smeared to determine if removable activity was present. Results from all smear analysis (Table 3, Removable alpha activity) were below the instrumentspecific MDA*.

\section{DIRECT AND REMOVABLE BETA-GAMMA RADIOACTIVITY LEVELS}

Beta-gamma dose rates were measured at 13 locations on the roof and 11 locations inside the building. Locations of the roof measurements and interior measurements are shown in Figs. 17 and 18, respe tivelv. Results are given in Table 3 with four additional measurements shown on Fig. 18. Beta-gamma dose rates ranged from 0.01 (Fig. 18) to 0.07 $\mathrm{mrad} / \mathrm{h}$ (Table 3 ), well below the guideline value of $0.2 \mathrm{mrad} / \mathrm{h}$ (Table 1). Smear analysis showed that removable beta-gamma activity at 13 location: on the roof and 7 locations inside the building was below the instrument-specific MDA* (Table 3, Removable betagamma activity).

\section{SOIL AND SHIELD-WALL FILL MATERIAL SAMPLES}

Radionuclide analysis was performed on soil and shield-wall samples collected at locations indicated in Fig. 18 (B). Results of analysis are listed in Table 4 (B). Concentrations of ${ }^{226} \mathrm{Ra},{ }^{232} \mathrm{Th}$, and ${ }^{238} \mathrm{U}$ in soil and shield material ranged from 3.6 to $8.1 \mathrm{pCi} / \mathrm{g}$, from 0.82 to $1.4 \mathrm{pCi} / \mathrm{g}$, and from 6.1 to $13 \mathrm{pCi} / \mathrm{g}$, respectively. All ${ }^{232} \mathrm{Th} / \mathrm{Tevels}$ were near typical background concentrations found in the Granite City area (Table 2) and below DOE guidelines of $5 \mathrm{pCi} / \mathrm{g}$ (Table 1). Concentrations of ${ }^{238} \mathrm{U}$ and ${ }^{226} \mathrm{Ra}$ were above typical background concentrations found in the Granite City area (Table 2), but, in all cases, these two radionuclides were in equilibrium, indicating that the sample material was of natural origin and not related to former AEC-sponsored activities at this site. Although no ${ }^{238} \mathrm{U}$ guidelines have been derived for this site, ${ }^{238} \mathrm{U}$ levels were below guidelines of 35 to $40 \mathrm{pCi} / \mathrm{g}$ applied at other FUSRAP sites (Table 1).

\section{DEBRIS SAMPLES}

Radionuclide analysis was performed on two debris samples collected at locations indicated in Fig. $18(\mathrm{M})$. Results of analysis are listed in Table 4 (M). Concentrations of ${ }^{226} \mathrm{Ra},{ }^{232} \mathrm{Th}$, and ${ }^{238} \mathrm{U}$ in sample M2 collected from a crack along the railroad track were $2.2,0.56$, and $3.0 \mathrm{pCi} / \mathrm{g}$, respectively, well within the expected range. Sample M1, collected at a small $\left(\sim 8\right.$-in. $\left.{ }^{2}\right)$ elevated spot $(0.1 \mathrm{mrad} / \mathrm{h})$ on a horizonial beam along the southeast wall of the building (Figs. 10 and 18), contained $33 \mathrm{pCi} / \mathrm{g}{ }^{226} \mathrm{Ra}, 5.6 \mathrm{pCi} / \mathrm{g}{ }^{232} \mathrm{Th}$, and $27 \mathrm{pCi} / \mathrm{g}$ ${ }^{238} \mathrm{U}$. When the counting error $( \pm 5)$ of the uranium analysis is included, ${ }^{226} \mathrm{Ra}$ and ${ }^{238} \mathrm{U}$ appear to be in equilibrium, indicating that the debris is of natural origin and not related to former AEC-sponsored activities at this site. 


\section{SIGNIFICANCE OF FINDINGS}

Radionuclide analysis of soil, shield-wall fill material, debris, and analysis of smear samples collected at the New Betatron Building, Granite City Steel facility, Granite City, Illinois, showed no residual ${ }^{238} \mathrm{U}$ attributable to former AEC-supported operations at this site. None of the indoor or outdoor gamma exposure rate measurements were elevated above DOE guidelines. The slight elevations in gamma levels found outdoors and on the roof over the shield wall are typical of naturally occurring radioactive substances present in coal ash, cinders, concrete, and other such materials found in these areas. The slight elevations of gamma levels found in soil samples can be attributed to the presence of naturally occurring radionuclides. In all samples, ${ }^{226} \mathrm{Ra}$ and ${ }^{238} \mathrm{U}$ appeared to be in equilibrium, indicatir.g that these radionuclides were of natural origin and not derived from former AEr-sponsored activities at this site.

\section{REFERENCES}

1. J. J. Fiore, U.S. Department of Energy, Washington, DC, letter (with attachments) to C. Cannon, Granite City Steel Company, Granite City, Illinois, June 1988.

2. DOE Order 5400.5, Radiation Protection of the Public and the Environment, April 1990 .

3. W. D. Cottrell and R. F. Carricr, Results of the Radiological Survey at the Granite City Steel Facility, Granite City, Illinois, ORNL/RASA-89/10, Martin Marietta Energy Systems, Inc., Oak Ridge Natl. Lab., July 1990.

4. T. E. Myrick, B. A. Berven, W. D. Cottrell, W. A. Goldsmith, and F. F. Haywood, Procedures Manual for the ORNL Radiological Survey Activities (RASA) Program, ORNL/TM-860), Martin Marictta Energy Systems, Inc., Oak Ridge Natl. Lab., April 1987. 


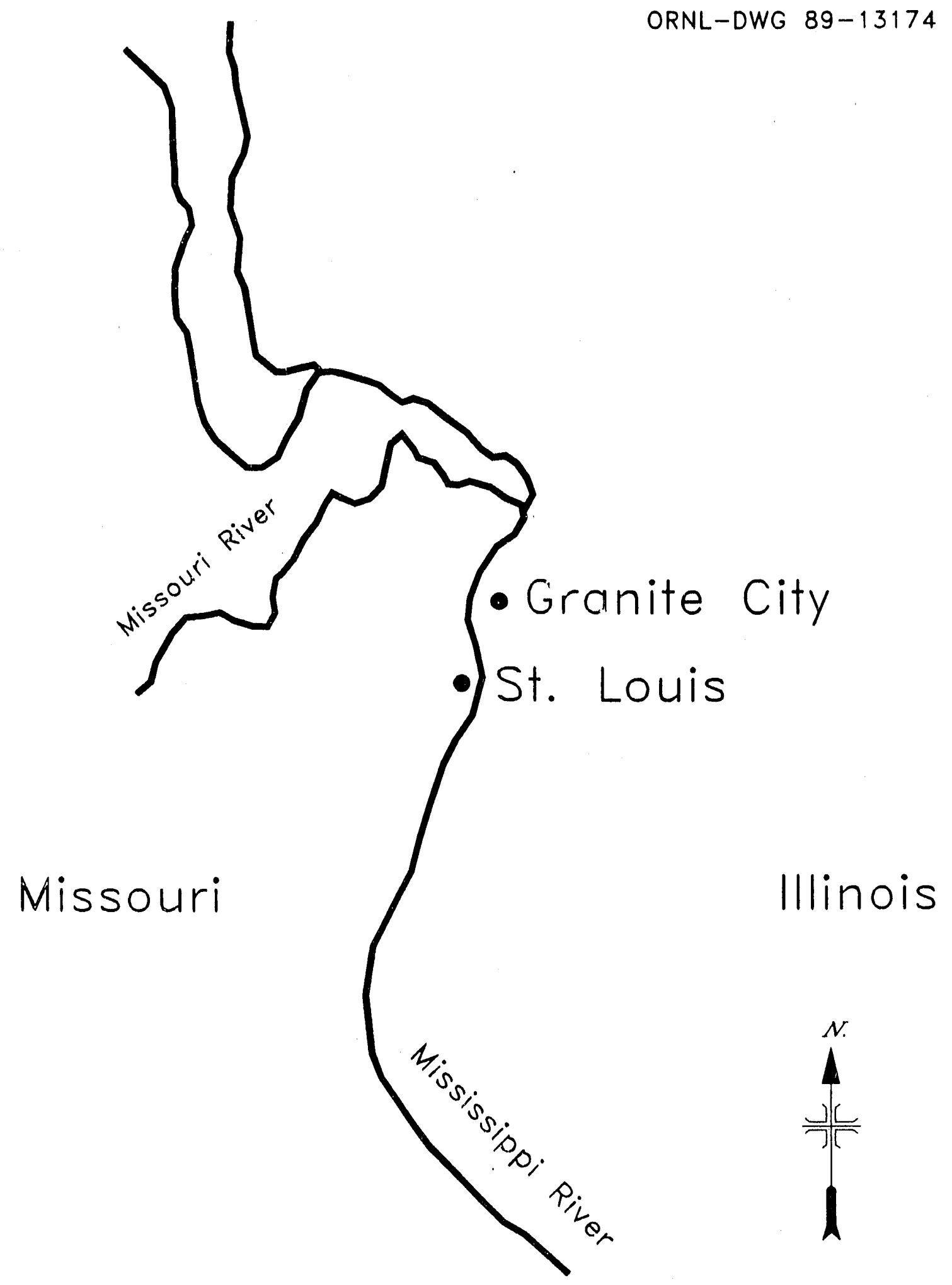

Fig. 1. General location of Granite City, Illinois. 


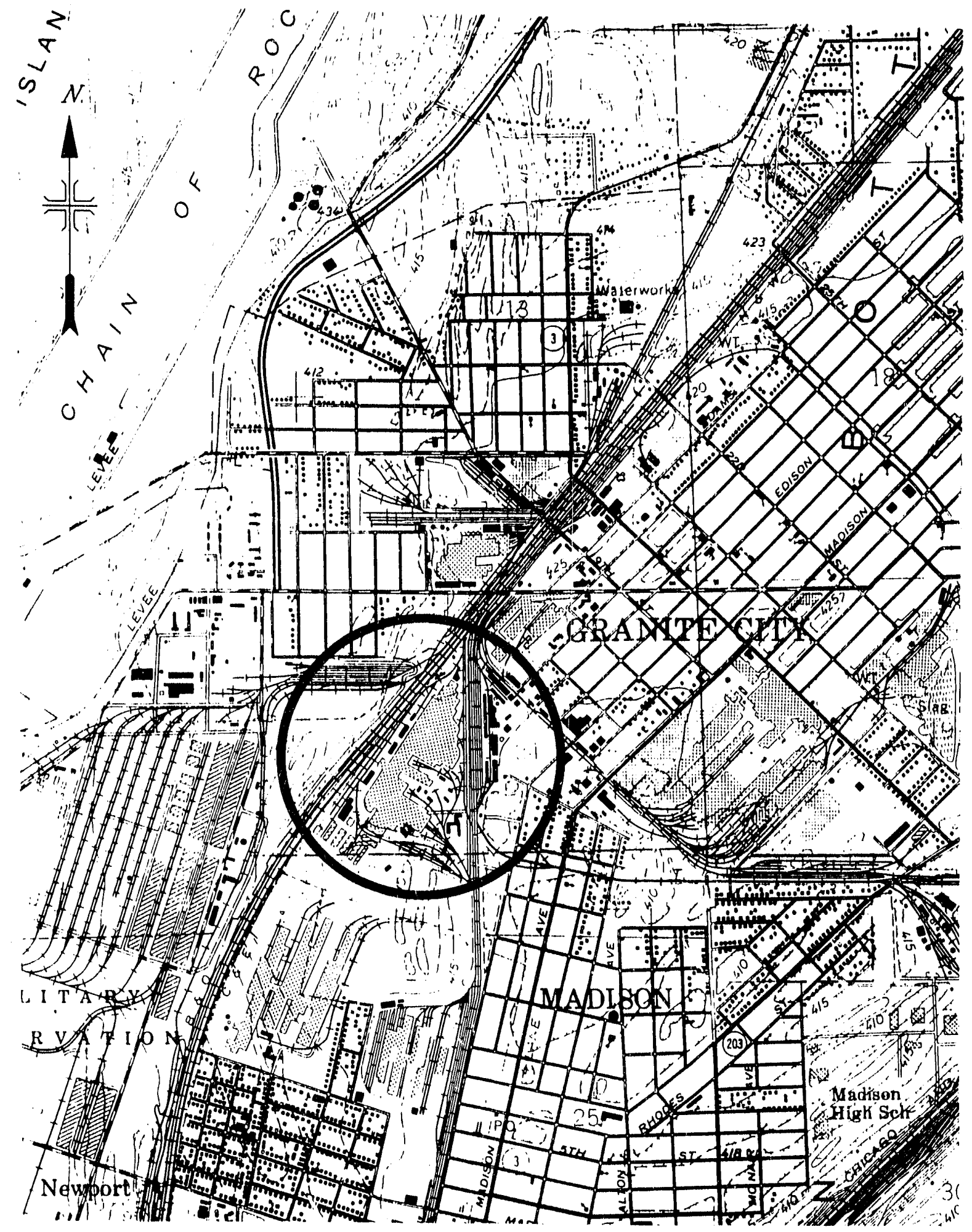

Fig. 2. Gencral location of the South Plant facility, Granite City Stecl Division, Granite City, Illinois. Source: "Granite City, Ill.- Mo." (topographic), N3837.5-W9007.5/7.5, AMS 2961 II NW-Scrics V863, U.S. Geological Survey, Reston, VA, 1974. 

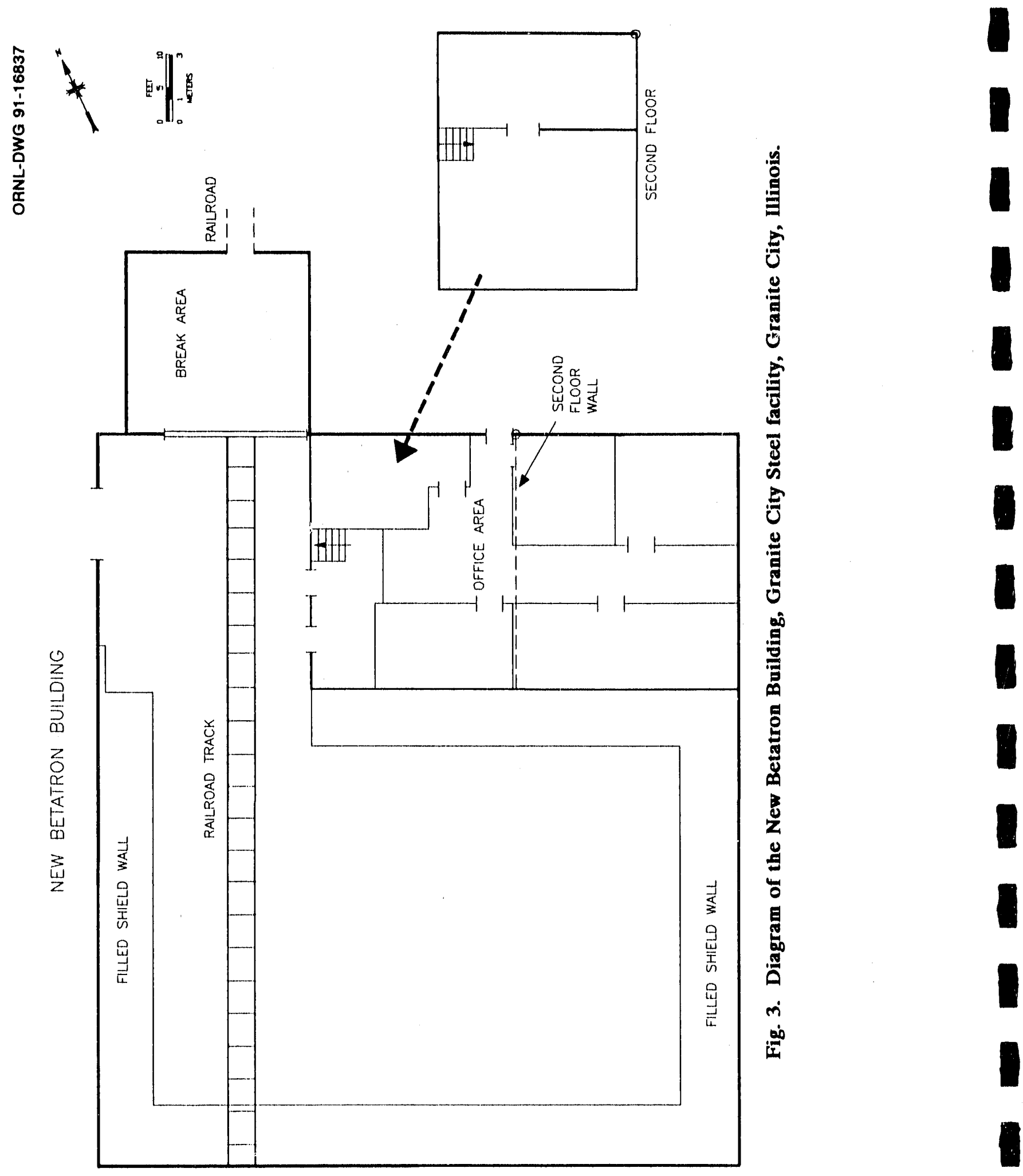

1 


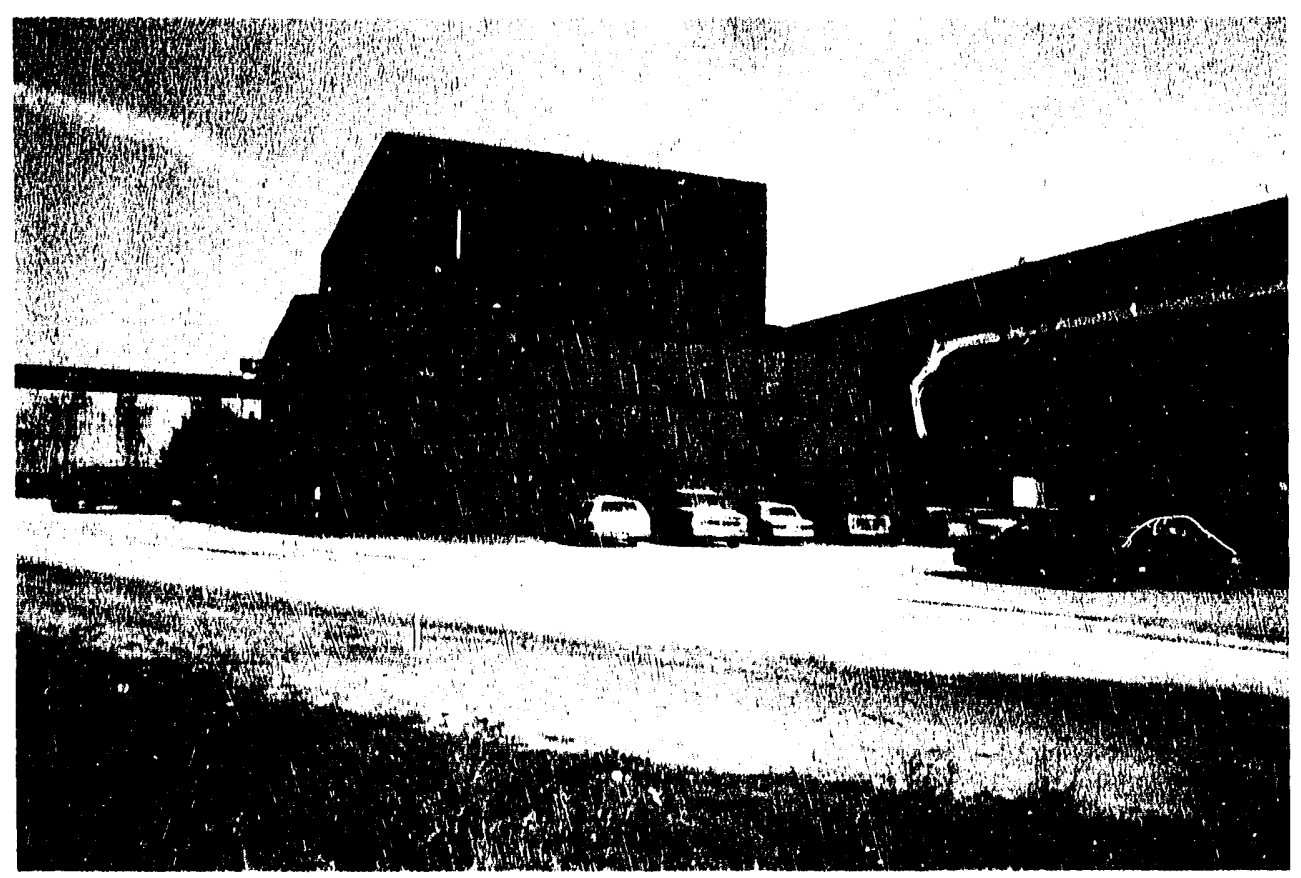

Fig. 4. View looking north northwest at the New Betatron Building, Granite City Stecl facility, Granite City, Illinois. Second floor rooms are shown at the far right of the photograph.

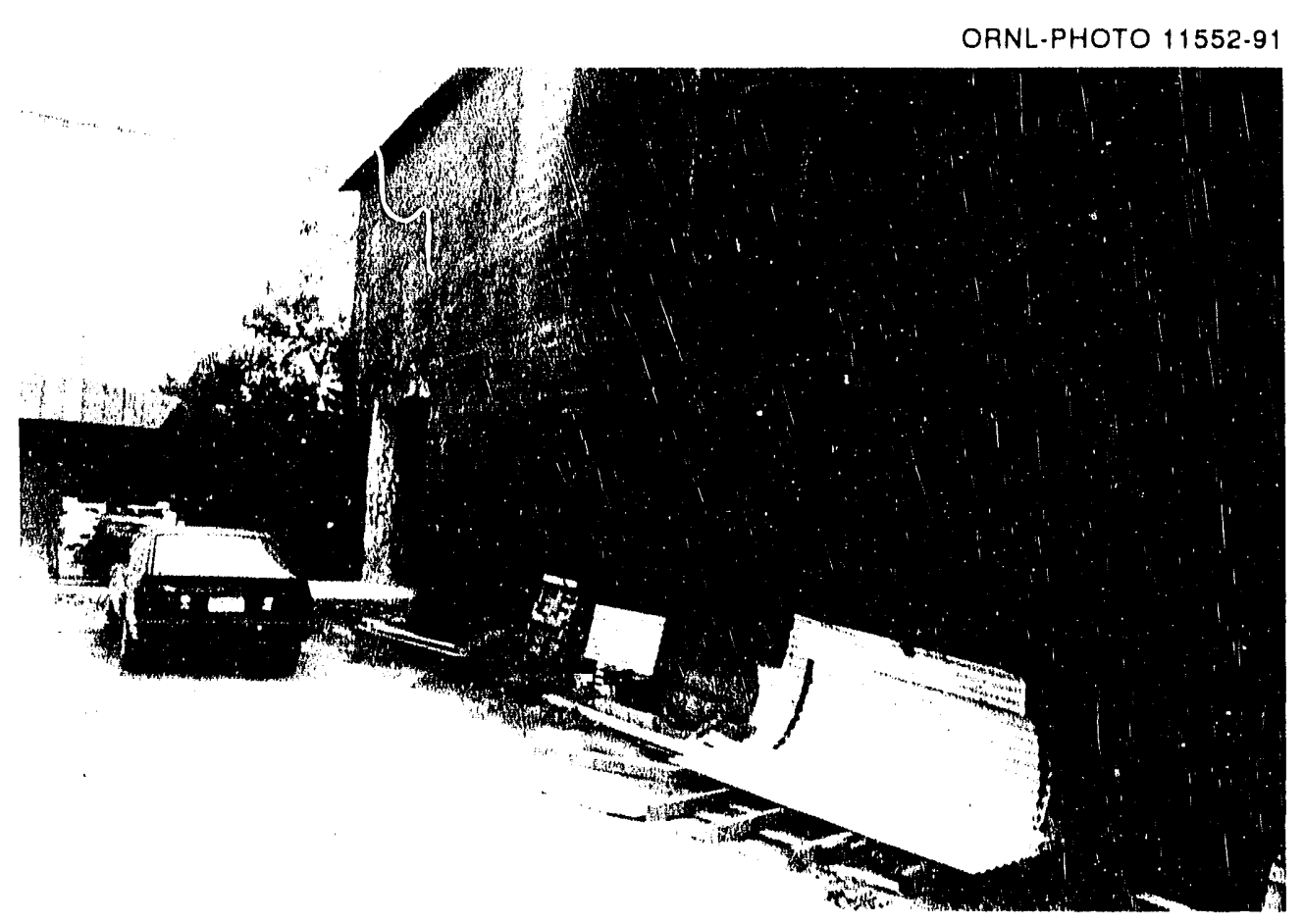

Fig. 5. View looking cast at entrance to the New Betatron Building, Granite City Stecl facility, Granite City, Illinois. 
ORNL.PHOTO 11553.91

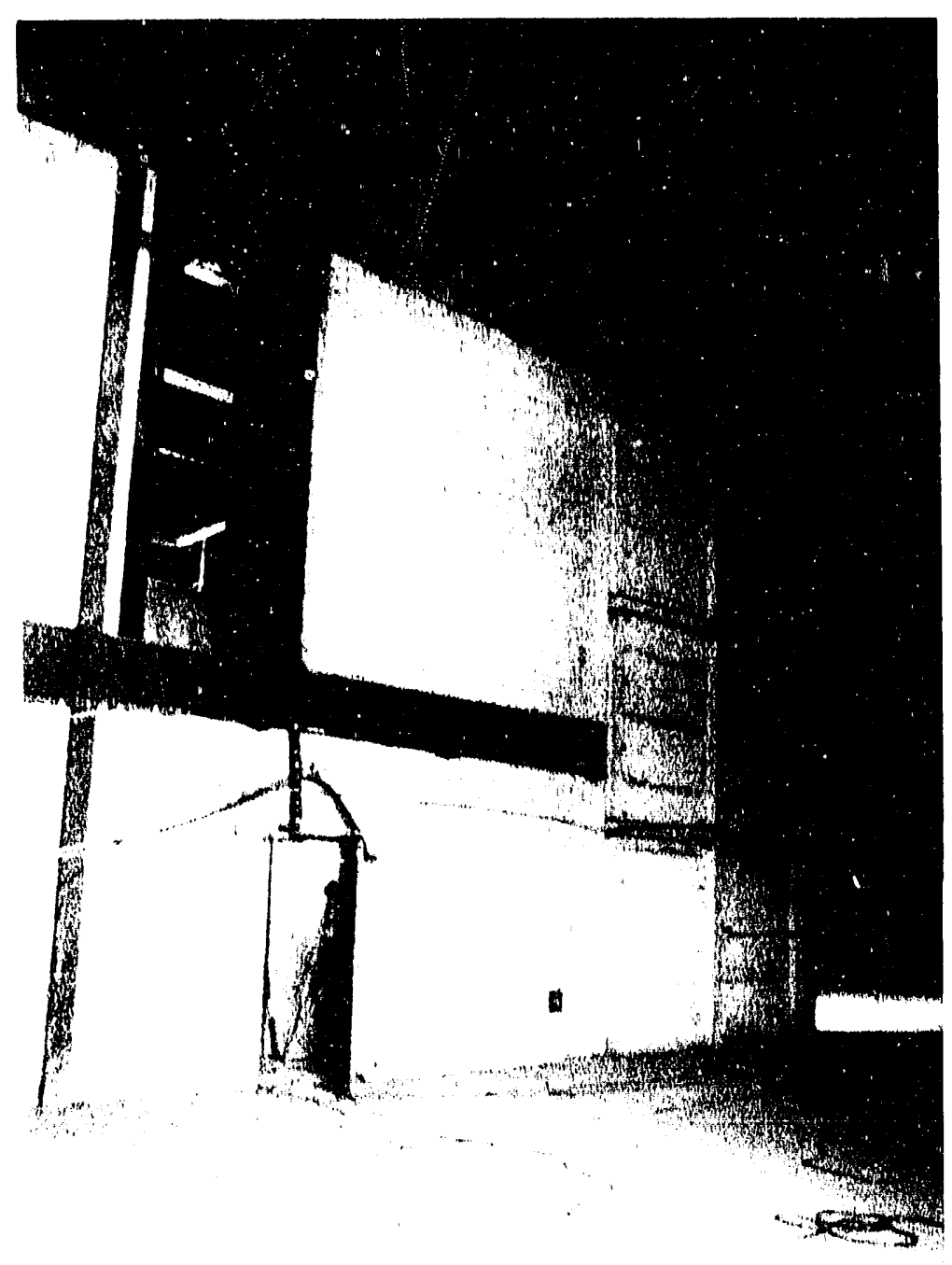

Fig. 6. Vicw looking south at entrance to interior rooms. 


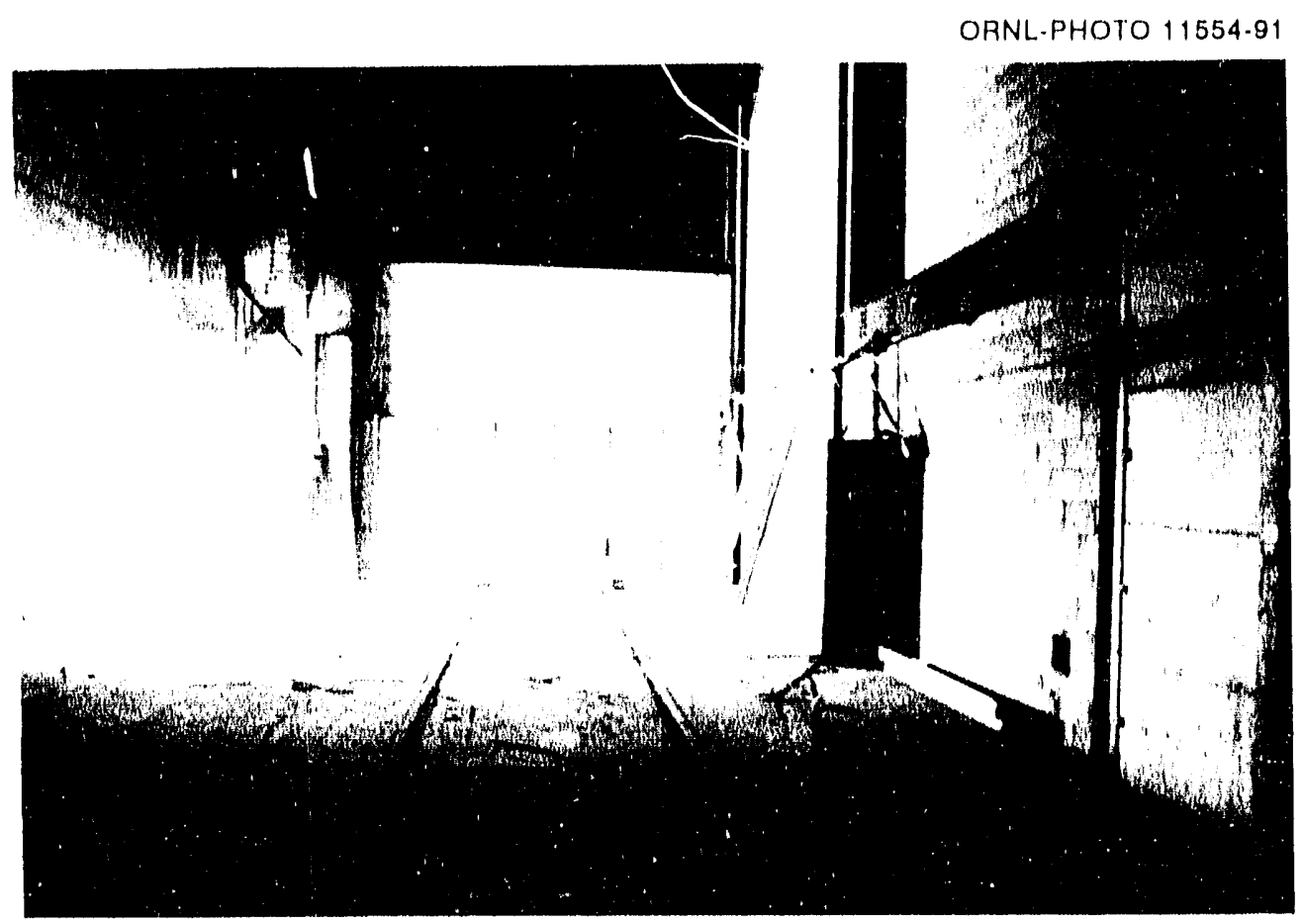

Fig. 7. Vicw looking northeast inside New Betatron Building with main entrance at left of photograph.

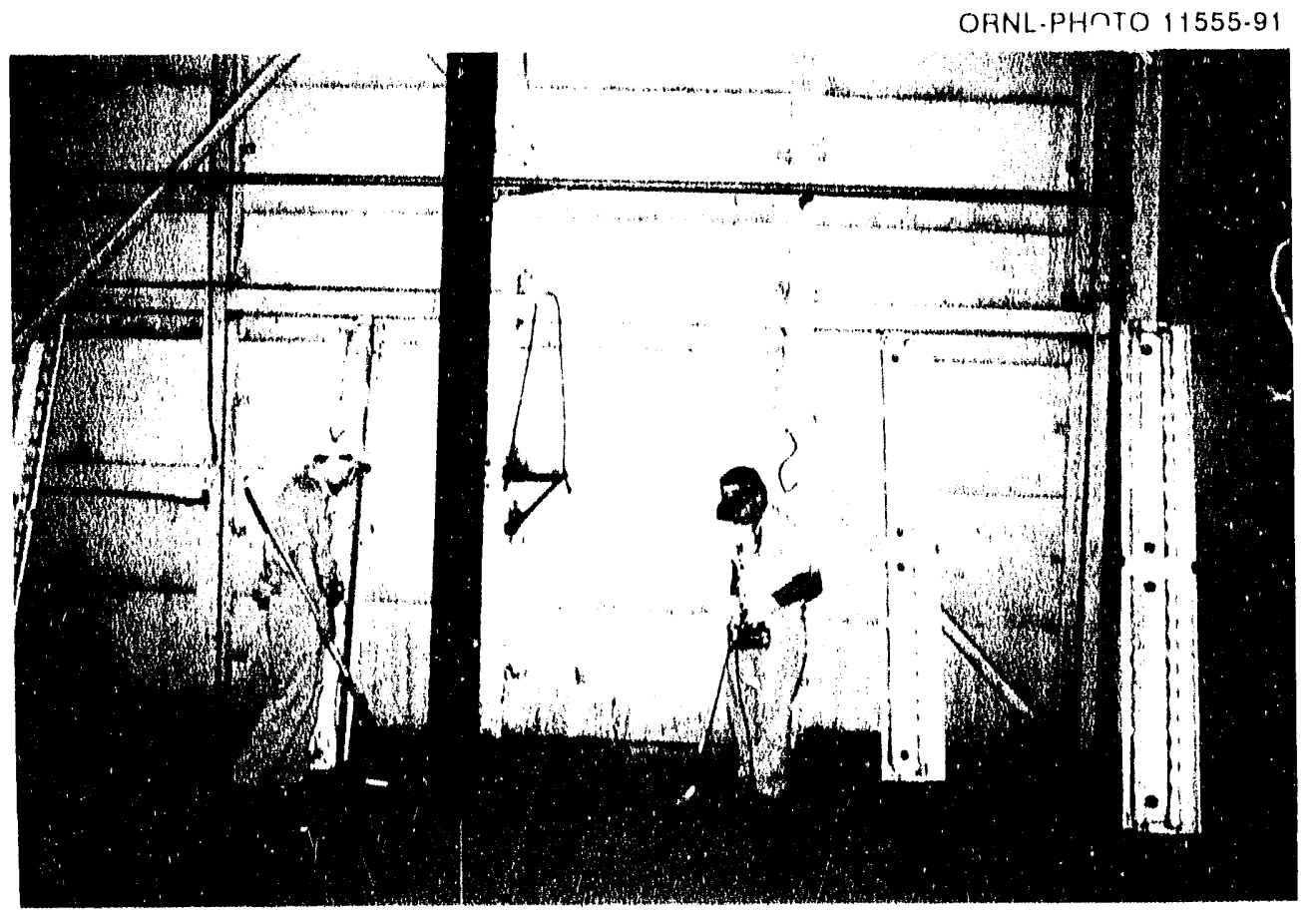

Fig. 8. Vicw of northwest wall in the New Betatron Building, Granite City Stecl facility. 
OANL.PPHOTO 11556.91

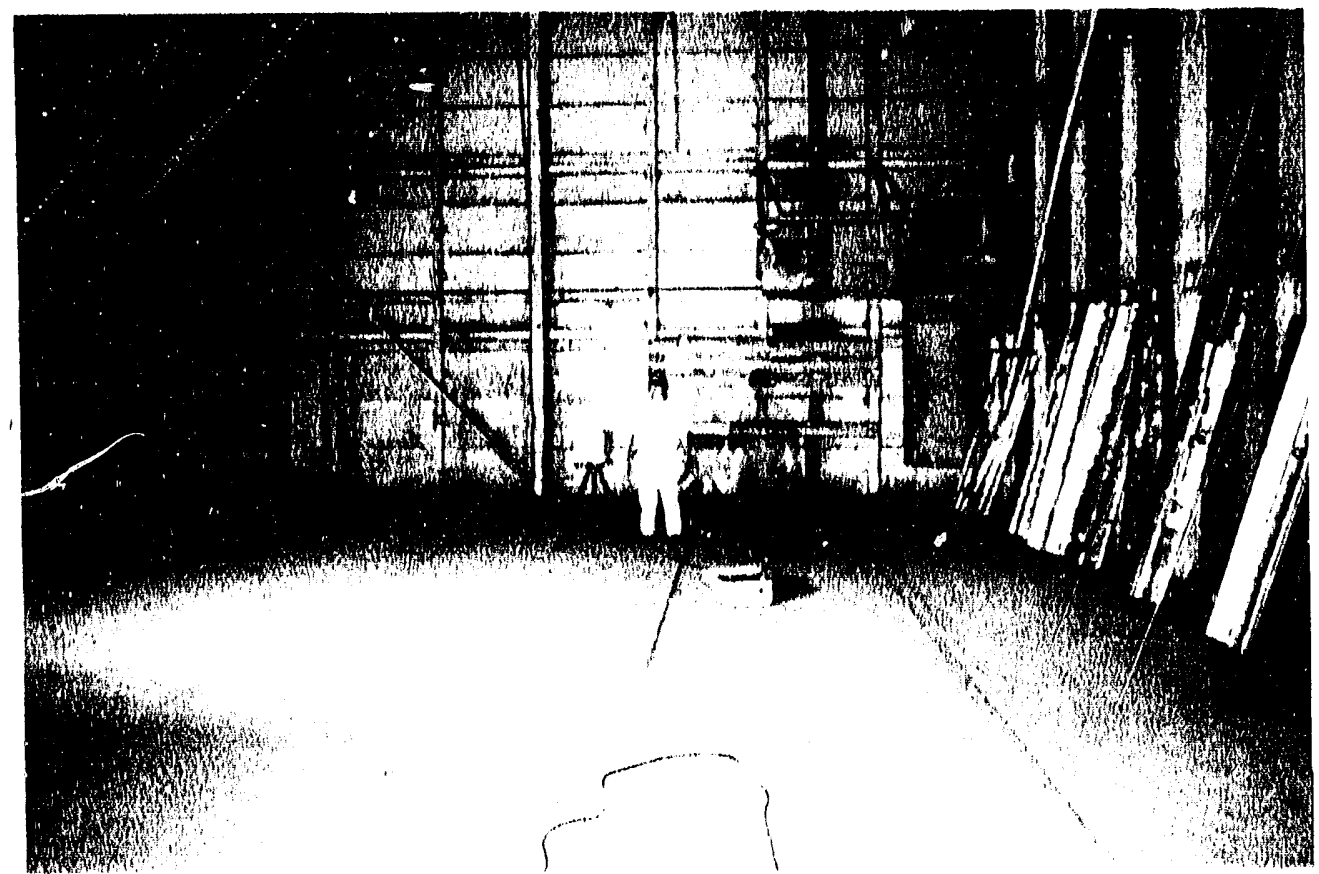

Fig. 9. View looking southwest inside the New Betatron Building, (iranitc City Stcel facility.

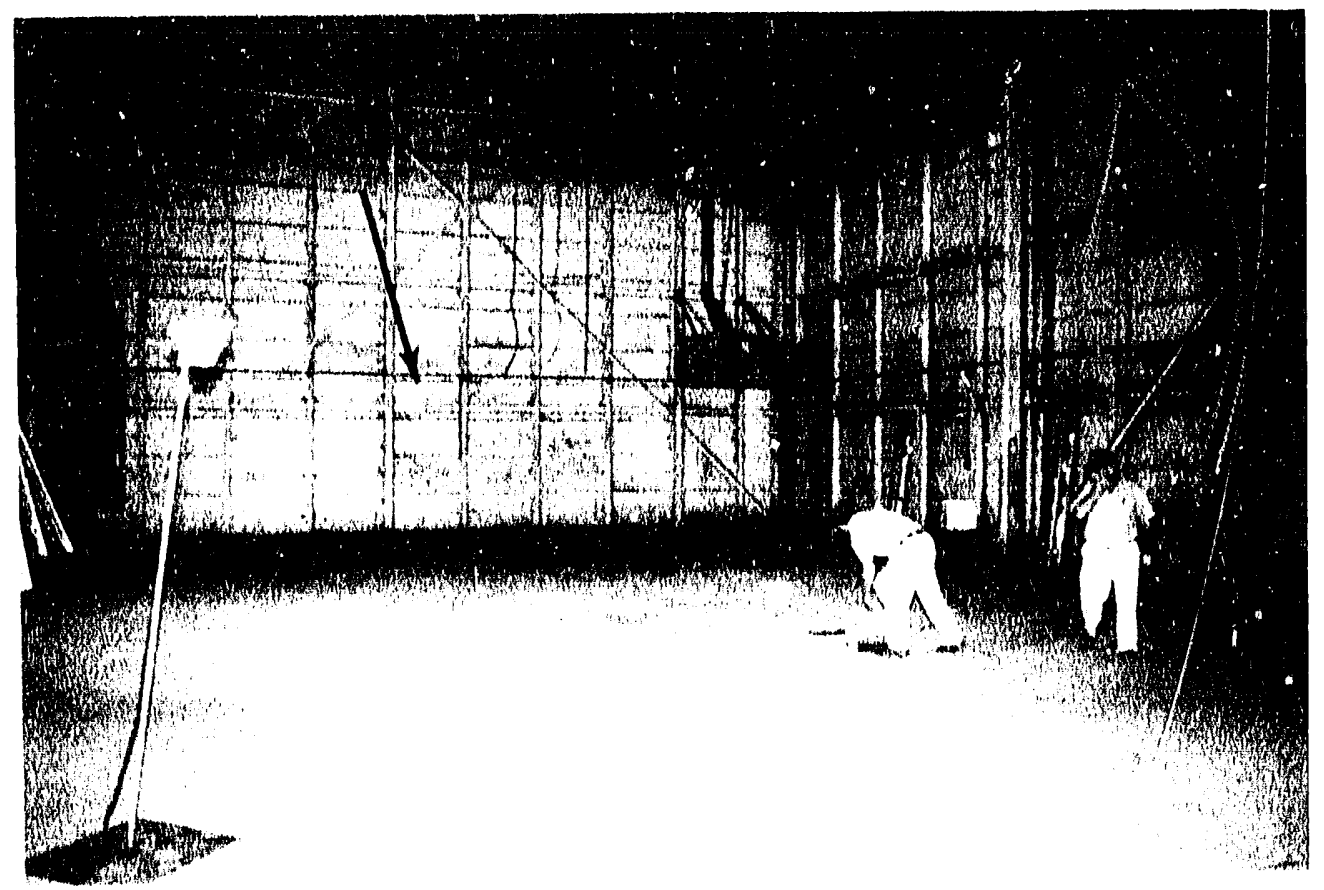

Fig. 10. Vicw looking, at southeast wall from the railroad track. Arrow denotes sumple location Ml. 


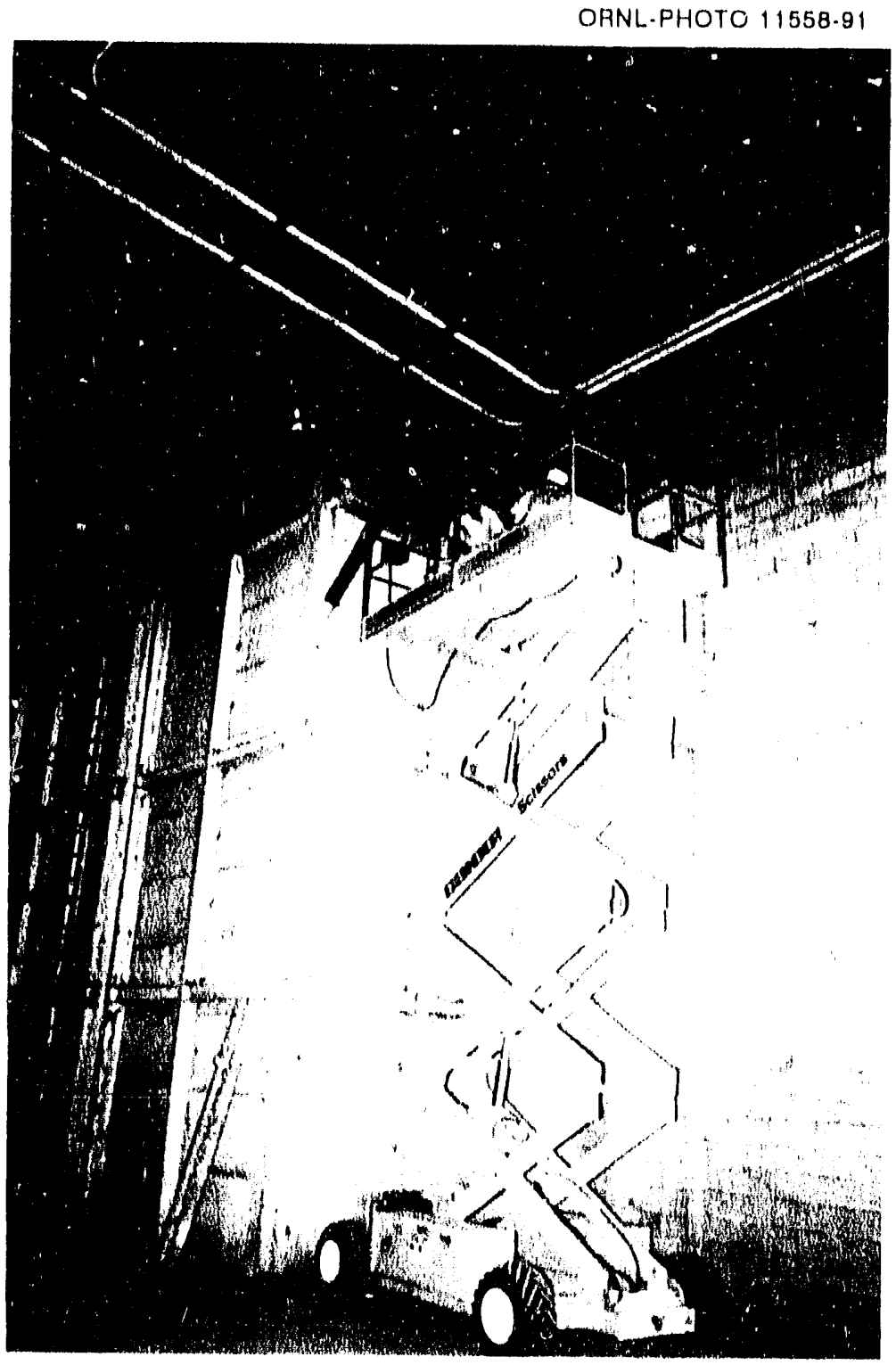

Fig. 11. View looking west at scissors lift used to access top of shicld wall and upper-fevel horizontal beams. 
OANL.PHOTO 11559.91

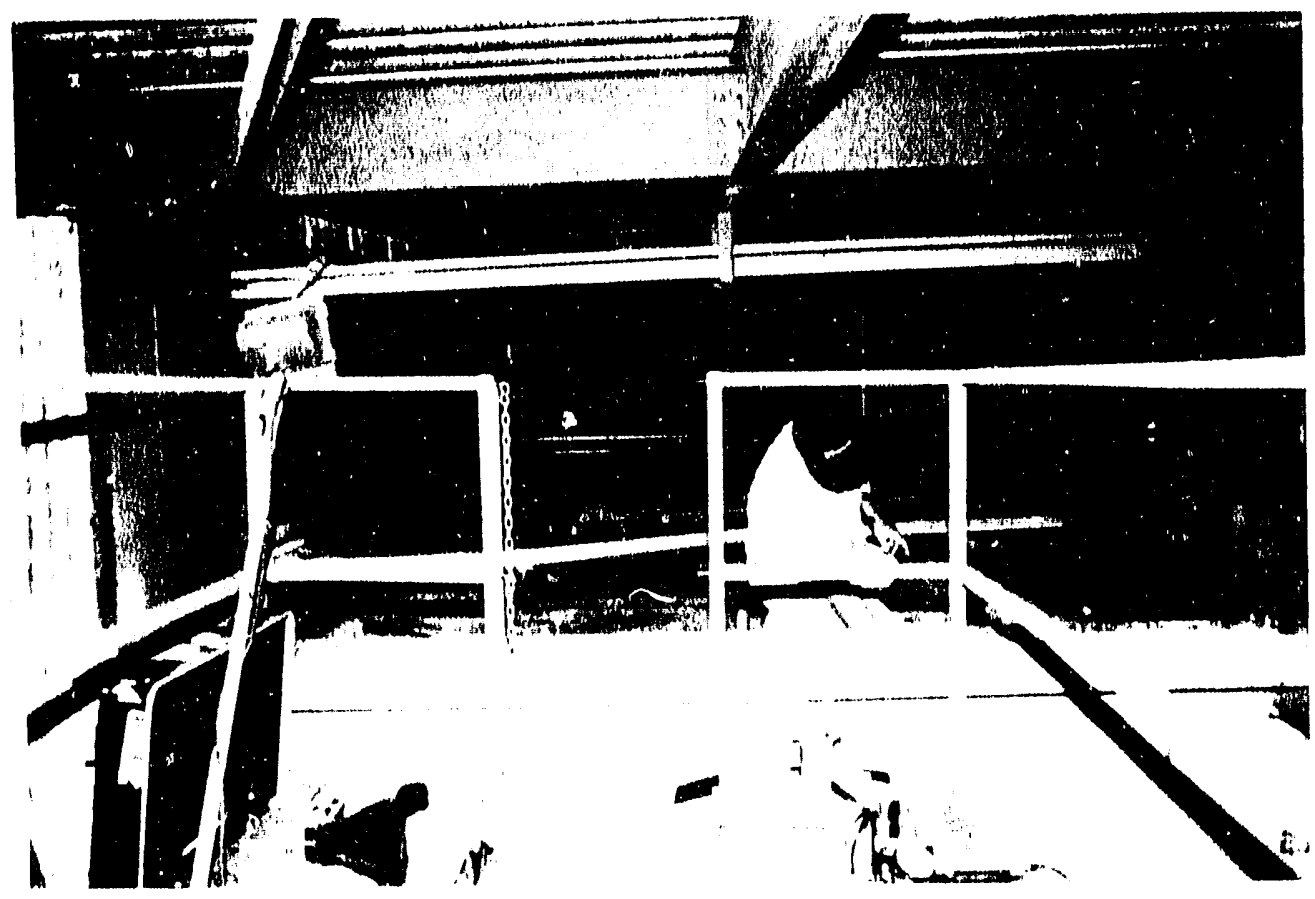

Fig. 12. Vicy of top of shicld wall from scissors lift.

ORNL-FHOTO 11560.91

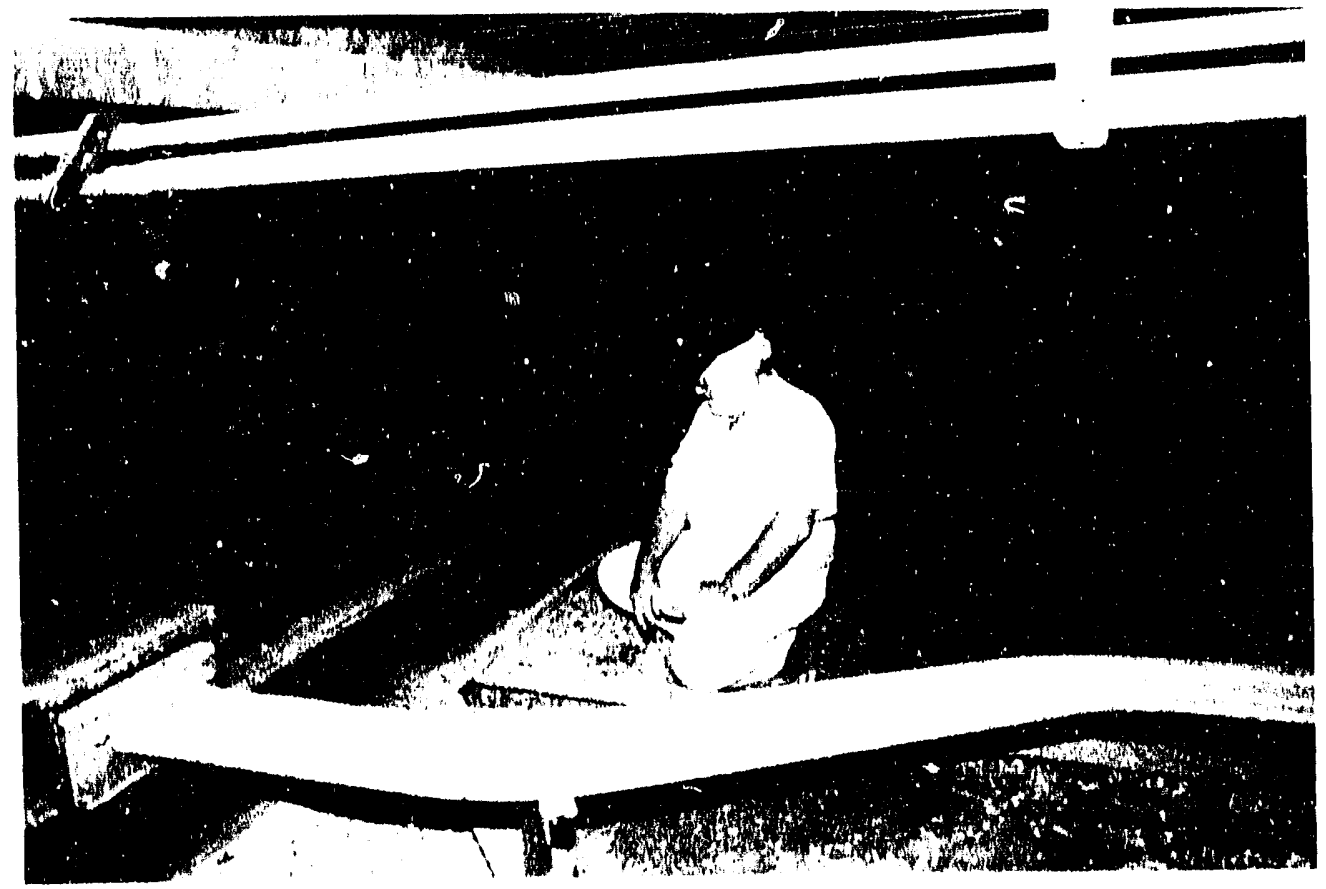

Fig. 13. Vicw on top of shicld wall looking southeast. 
ORNL.PHOTO 11561.91

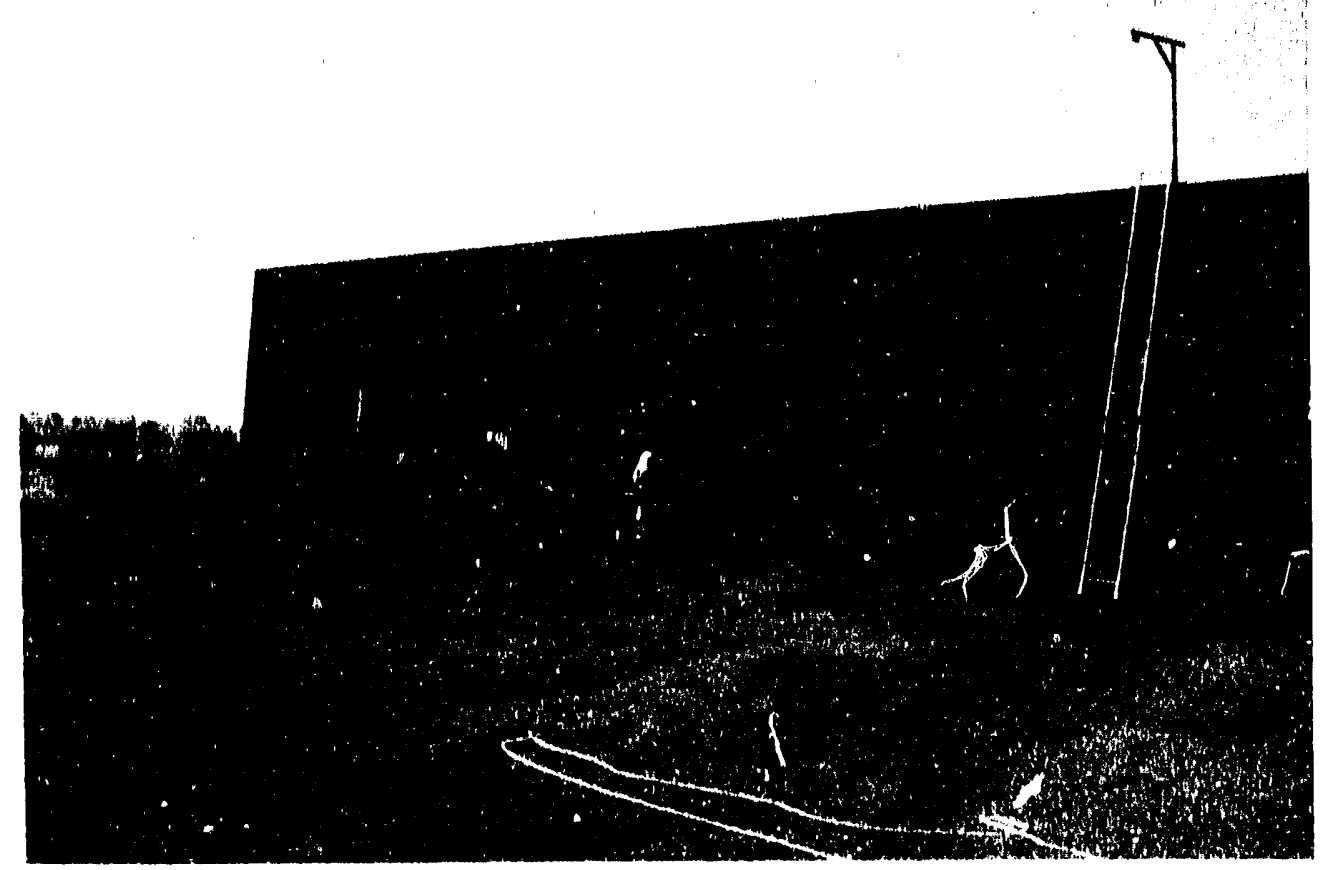

Fig. 14. View looking south at vent 4 on flat roof above second floor rooms. Ladder at right was used to access top of building.

ORNL.PHOTO 11562.91

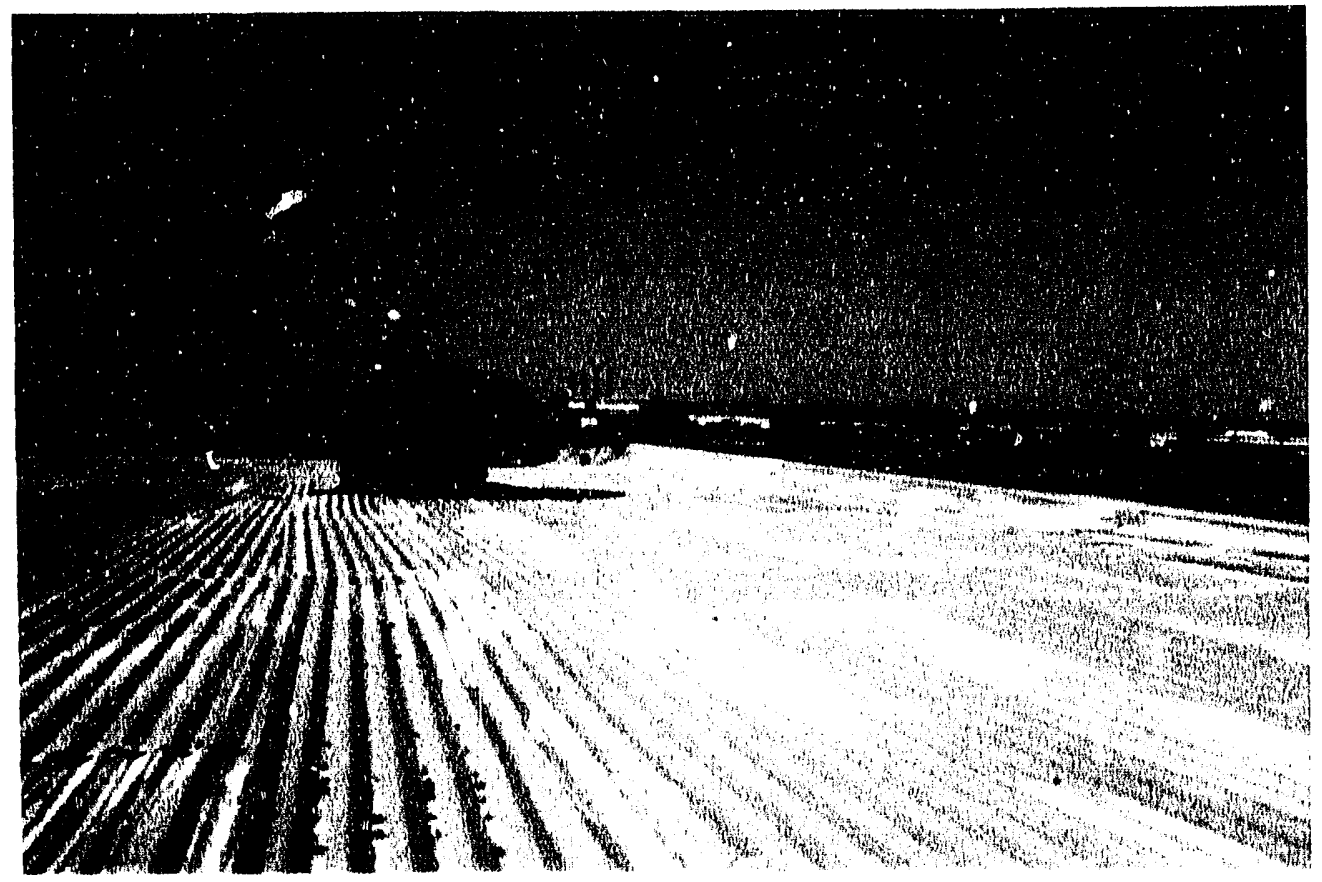

Fig. 15. View on top of New Betatron Building looking west at air vent 1 . 

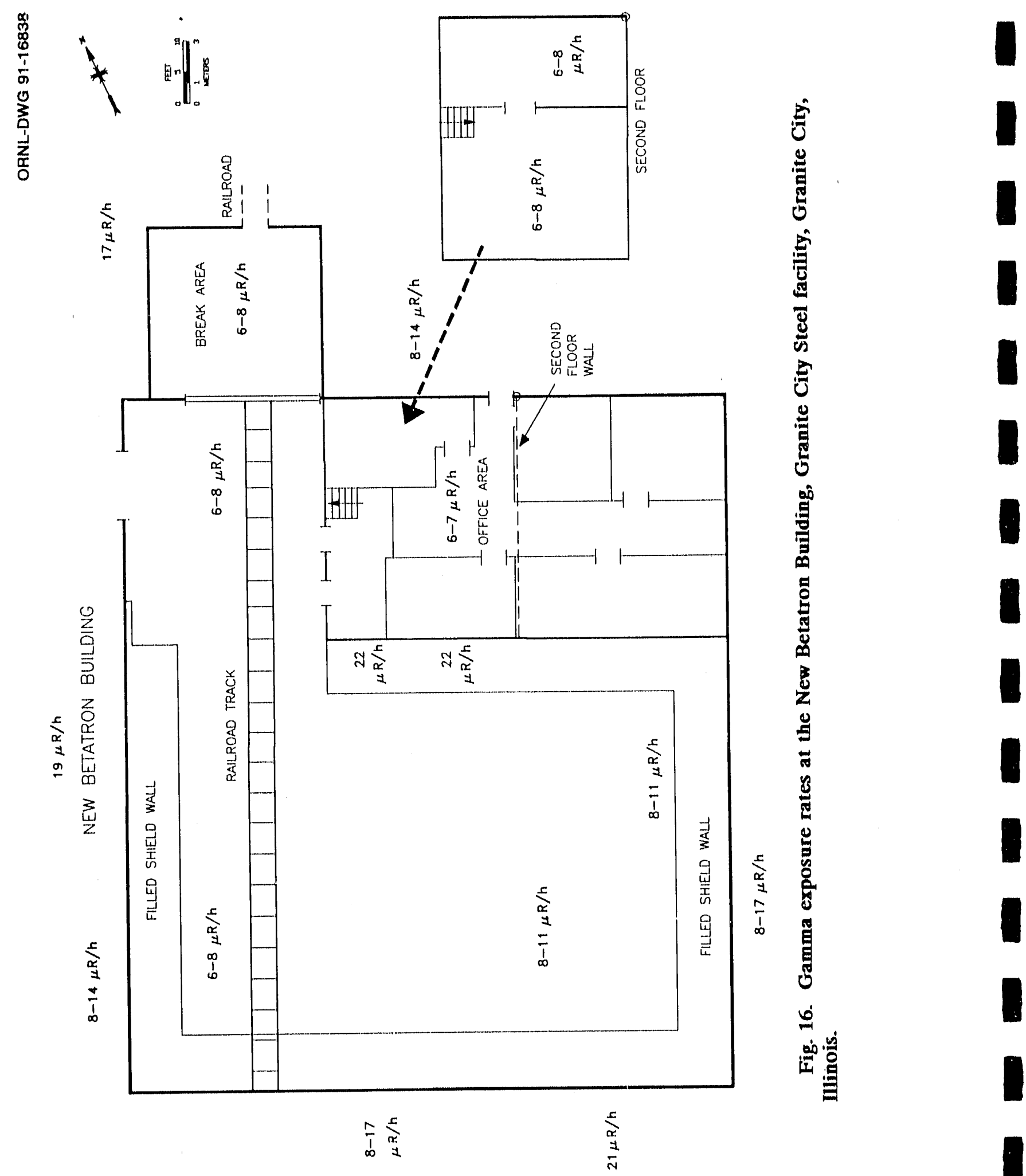

宣
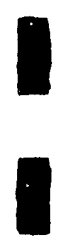

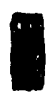



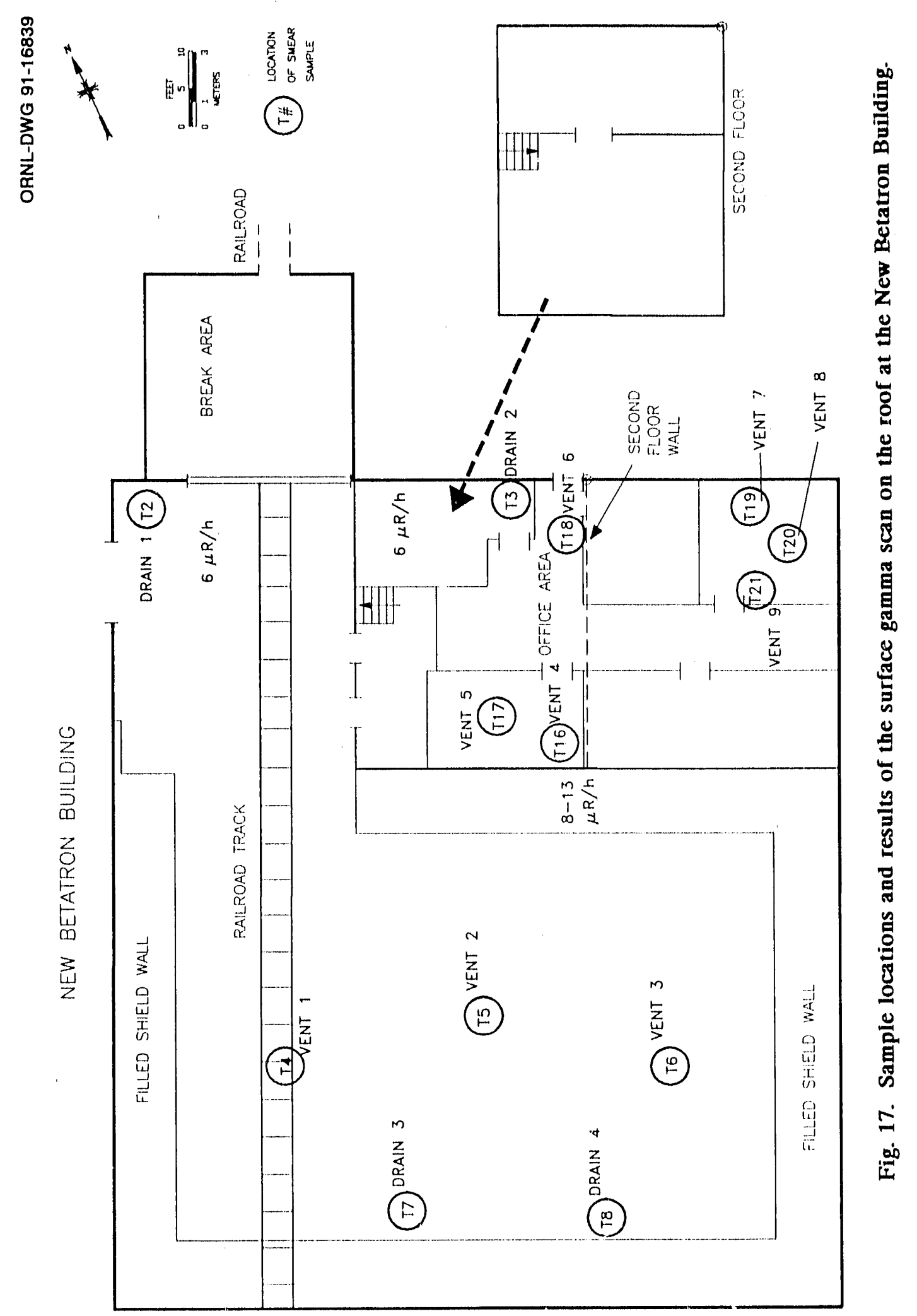

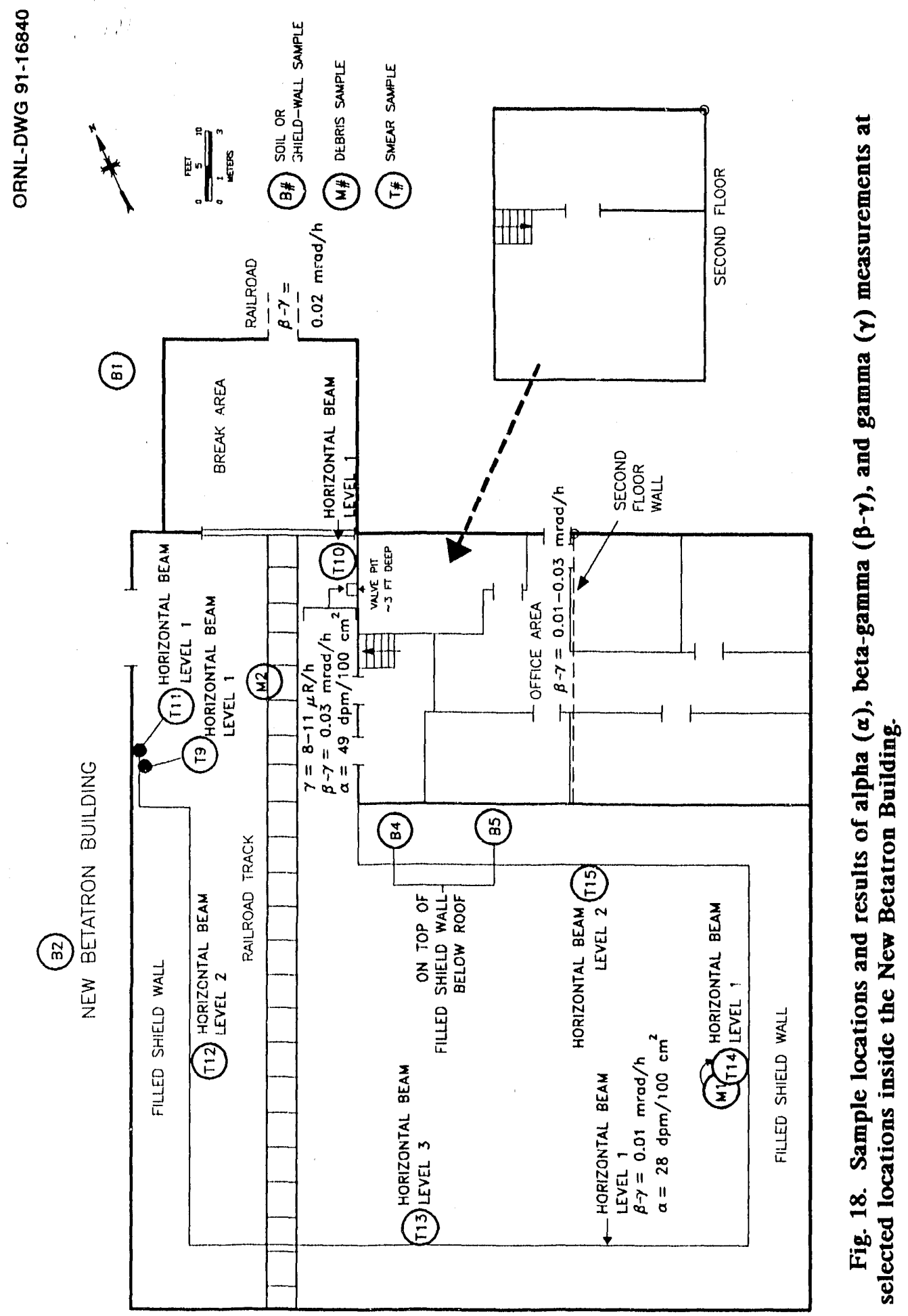

(m) 
Table 1. Applicable guidelines for protection against radiation

(Limits for uncontrolled areas)

\begin{tabular}{|c|c|c|}
\hline Mode of exposure & Exposure conditions & Guideline value \\
\hline Gamma radiation & $\begin{array}{l}\text { Indoor gamma radiation level } \\
\text { (above background) }\end{array}$ & $20 \mu \mathrm{R} / \mathrm{h}^{a}$ \\
\hline \multirow[t]{14}{*}{$\begin{array}{l}\text { Total residual surface } \\
\text { contamination }^{b}\end{array}$} & $\begin{array}{l}{ }^{238} \mathrm{U},{ }^{235} \mathrm{U}, \mathrm{U} \text {-natural (alpha } \\
\text { emitters) }\end{array}$ & \\
\hline & Beta-gamma emitters ${ }^{c}$ & \\
\hline & Maximum & $15,000 \mathrm{dpm} / 100 \mathrm{~cm}^{2}$ \\
\hline & Average & $5,000 \mathrm{dpm} / 100 \mathrm{~cm}^{2}$ \\
\hline & Removable & $1,000 \mathrm{dpm} / 100 \mathrm{~cm}^{2}$ \\
\hline & $\begin{array}{l}{ }^{232} \mathrm{Th} \text {, Th-natural (alpha } \\
\text { emitters) }\end{array}$ & \\
\hline & ${ }^{90} \mathrm{Sr}$ (beta-gamma emitter) & \\
\hline & Maximum & $3,000 \mathrm{dpm} / 100 \mathrm{~cm}^{2}$ \\
\hline & Average & $1,000 \mathrm{dpm} / 100 \mathrm{~cm}^{2}$ \\
\hline & Removable & $200 \mathrm{dpm} / 100 \mathrm{~cm}^{2}$ \\
\hline & ${ }^{226} \mathrm{Ra},{ }^{230} \mathrm{Th}$, transuranics & \\
\hline & Maximum & $300 \mathrm{dpm} / 100 \mathrm{~cm}^{2}$ \\
\hline & Average & $100 \mathrm{dpm} / 100 \mathrm{~cm}^{2}$ \\
\hline & Removable & $20 \mathrm{dpm} / 100 \mathrm{~cm}^{2}$ \\
\hline \multirow[t]{2}{*}{$\begin{array}{l}\text { Beta-gamma dose } \\
\text { rates }\end{array}$} & $\begin{array}{l}\text { Surface dose rate averaged } \\
\text { over not more than } 1 \mathrm{~m}^{2}\end{array}$ & $0.20 \mathrm{mrad} / \mathrm{h}$ \\
\hline & $\begin{array}{l}\text { Maximum dose rate in any } \\
10()-\mathrm{cm}^{2} \text { area }\end{array}$ & $1.0 \mathrm{mrad} / \mathrm{h}$ \\
\hline $\begin{array}{l}\text { Radionuclide con- } \\
\text { centrations in soil } \\
\text { (generic) }\end{array}$ & $\begin{array}{l}\text { Maximum permissible con- } \\
\text { centration of the following } \\
\text { radionuclides in soil above } \\
\text { background levels, averaged } \\
\text { over a } 100-\mathrm{m}^{2} \text { area } \\
{ }^{226} \mathrm{Ra} \\
{ }^{232} \mathrm{Th} \\
{ }^{230} \mathrm{Th}\end{array}$ & $\begin{array}{l}5 \mathrm{pCi} / \mathrm{g} \text { averaged over the } \\
\text { first } 15 \mathrm{~cm} \text { of soil below } \\
\text { the surface; } 15 \mathrm{pCi} / \mathrm{g} \\
\text { when averaged over } \\
15-\mathrm{cm} \text {-thick soil layers } \\
\text { more than } 15 \mathrm{~cm} \text { below } \\
\text { the surface }\end{array}$ \\
\hline
\end{tabular}


Table 1 (continued)

\begin{tabular}{lcl}
\hline Mode of Exposure & Exposure conditions & Guideline value \\
\hline Derived concentrations & ${ }^{238} \mathrm{U}$ & Site specific $^{d}$ \\
\hline
\end{tabular}

${ }^{a}$ The $20 \mu \mathrm{R} / \mathrm{h}$ shall comply with the basic dose limit (100 mrem/year) when an appropriate-use scenario is considered.

${ }^{b}$ DOE surface contamination guidelines are consistent with NRC Guidelines for Decontamination at Facilities and Equipment Prior to Release for Unrestricted Use or Termination of Licenses for By-Product, Source, or Special Nuclear Material, May 1987.

'Beta-gamma emitters (radionuclides with decay modes other than alpha emission or spontaneous fission) except ${ }^{90} \mathrm{Sr},{ }^{228} \mathrm{Ra},{ }^{223} \mathrm{Ra},{ }^{227} \mathrm{Ac},{ }^{133} \mathrm{I},{ }^{129} \mathrm{I},{ }^{126} \mathrm{I},{ }^{125} \mathrm{I}$.

${ }^{d} \mathrm{DOE}$ guidelines for uranium are derived on a site-specific basis. Guidelines of $35-40 \mathrm{pCi} / \mathrm{g}$ have been applied at other FUSRAP sites. Sourc: J. L. Marley and R. F. Carrier, Results of the Radiological Survev at 4 Elmhurst Avenue, Colonie, New York (AL219), ORNL/RASA-87/117, Martin Marietta Ene:gy Systems, Inc., Oak Ridge Natl. Lab., February 1988; B. A. Berven et al., Radiological Survey of the Former Kellex Research Facility, Jersey City, New Jersey, DOE/EV0005/29, ORNL-5734, Martin Marietta Energy Systems, Inc., Oak Ridge Natl. Lab., February 1982.

Sources: Adapted from U.S. Department of Energy, DOE Order 5400.5, April 1990, and U.S. Department of Energy, Guidelines for Residual Radioactive Material at Formerly Utilized Sites Remedial Action Program and Remote Surplus Facilities Management Program Sites, Rev. 2, March 1987. 
Table 2. Background radiation levels for the Granite City, Illinois, area

\begin{tabular}{lcc}
\hline \multirow{2}{*}{$\begin{array}{c}\text { Type of radiation measurement } \\
\text { or sample }\end{array}$} & $\begin{array}{c}\text { Radiation level or radionuclide } \\
\text { concentration }\end{array}$ \\
\cline { 2 - 3 } & Range & Average \\
\hline $\begin{array}{c}\text { Gamma exposure rate at } 1 \mathrm{~m} \\
\text { above ground surface }(\mu \mathrm{R} / \mathrm{h})^{a}\end{array}$ & $7-11$ & 9 \\
Concentration of radionuclides \\
$\begin{array}{l}\text { in soil (pCi/g dry wt) } \\
{ }^{232} \mathrm{Th}^{b}\end{array}$ & $1.0-1.2$ & \\
${ }^{226} \mathrm{Ra}^{c}$ & $0.88-0.93$ & 1.1 \\
${ }^{238} \mathrm{U}^{b}$ & $1.0-1.1$ & 0.90 \\
\end{tabular}

${ }^{a}$ Exposure rate determined from 3 to 4 measurements at each of 3 locations.

${ }^{b}$ Data collected from 3 sampling locations.

'Data collected from 2 sampling locations.

Source: T. E. Myrick, B. A. Berven, and F. F. Haywood, State Background Radiation Levels: Results of Measurements Taken During 1975-1979, ORNL/TM-7343, Martin Marietta Energy Systems, Inc., Oak Ridge Natl. Lab., November 1981. 
Table 3. Alpha and beta-gamma measurements at the New Betatron Building, Granite City Steel facility, 1417 State Strect, Granite City, Illinois

\begin{tabular}{|c|c|c|c|c|c|}
\hline \multirow[b]{2}{*}{ Sample ${ }^{a}$} & \multicolumn{2}{|c|}{ Directly measured radioactivity } & \multicolumn{2}{|c|}{ Removable radioactivity ${ }^{d}$} & \multirow[b]{2}{*}{ Location } \\
\hline & $\begin{array}{c}\text { Alpha } \\
\left(\mathrm{dpm} / 100 \mathrm{~cm}^{2}\right) \\
\end{array}$ & $\begin{array}{c}\text { Beta-gamma } \\
(\mathrm{mrad} / \mathrm{h})\end{array}$ & $\begin{array}{c}\text { Alphae } \\
\left(\mathrm{dpm} / 100 \mathrm{~cm}^{2}\right)\end{array}$ & $\begin{array}{c}\text { Beta-gamma } \\
\left(\mathrm{dpm} / 100 \mathrm{~cm}^{2}\right)\end{array}$ & \\
\hline $\mathrm{T} 2$ & 49 & 0.03 & $<10$ & $<200$ & $\begin{array}{c}\text { Roof drain } \\
1\end{array}$ \\
\hline $\mathrm{T} 3$ & 91 & 0.03 & $<10$ & $<200$ & $\begin{array}{l}\text { Roof drain } \\
\quad 2\end{array}$ \\
\hline $\mathrm{T} 4$ & $<25$ & 0.02 & $<10$ & $<200$ & $\begin{array}{c}\text { Roof vent } \\
1\end{array}$ \\
\hline T5 & 42 & 0.02 & $<10$ & $<200$ & $\begin{array}{c}\text { Roof vent } \\
2\end{array}$ \\
\hline T6 & $<25$ & 0.02 & $<10$ & $<200$ & $\begin{array}{c}\text { Roof vent } \\
3\end{array}$ \\
\hline $\mathrm{T} 7$ & 56 & 0.02 & $<10$ & $<200$ & $\begin{array}{l}\text { Roof drain } \\
\quad 3\end{array}$ \\
\hline $\mathrm{T} 8$ & 77 & 0.02 & $<10$ & $<200$ & $\begin{array}{c}\text { Roof drain } \\
4\end{array}$ \\
\hline $\mathrm{T} 9$ & $<25$ & 0.02 & $<10$ & $<200$ & $\begin{array}{c}\text { Horizontal } \\
\text { beam, level } \\
1\end{array}$ \\
\hline $\mathrm{T} 10$ & $<25$ & 0.02 & $<10$ & $<200$ & $\begin{array}{c}\text { Horizontal } \\
\text { beam, level } \\
1\end{array}$ \\
\hline T11 & 35 & 0.02 & $<10$ & $<200$ & $\begin{array}{c}\text { Horizontal } \\
\text { beam, level } \\
1\end{array}$ \\
\hline $\mathrm{T} 12$ & $<25$ & 0.02 & $<10$ & $<200$ & $\begin{array}{l}\text { Horizontal } \\
\text { beam, lcvel } \\
2\end{array}$ \\
\hline $\mathrm{T} 13$ & 28 & 0.02 & $<10$ & $<200$ & $\begin{array}{c}\text { Horizontal } \\
\text { beam, level } \\
3\end{array}$ \\
\hline $\mathrm{T} 14$ & $<25$ & 0.07 & $<10$ & $<200$ & $\begin{array}{c}\text { Horizontal } \\
\text { beam, level } \\
1\end{array}$ \\
\hline $\mathrm{T} 15$ & $<25$ & 0.03 & $<10$ & $<200$ & $\begin{array}{c}\text { Horizontal } \\
\text { beam, level } \\
2\end{array}$ \\
\hline T16 & 121 & 0.02 & $<10$ & $<200$ & $\begin{array}{c}\text { Roof vent } \\
4\end{array}$ \\
\hline
\end{tabular}


Table 3 (continued)

\begin{tabular}{cccccc}
\hline Sample $^{a}$ & \multicolumn{2}{c}{ Directly measured radioactivity } & \multicolumn{2}{c}{ Removable radioactivity } & Location \\
\cline { 2 - 5 } & $\begin{array}{c}\text { Alpha } \\
\left(\mathrm{dpm} / 100 \mathrm{~cm}^{2}\right)\end{array}$ & $\begin{array}{c}\text { Beta-gamma } \\
(\mathrm{mrad} / \mathrm{h})\end{array}$ & $\begin{array}{c}\text { Alpha } \\
\left(\mathrm{dpm} / 100 \mathrm{~cm}^{2}\right)\end{array}$ & $\begin{array}{c}\text { Beta-gammaf } \\
\left(\mathrm{dpm} / 100 \mathrm{~cm}^{2}\right)\end{array}$ & \\
\hline $\mathrm{T} 17$ & 77 & 0.03 & $<10$ & $<200$ & $\begin{array}{c}\text { Roof vent } \\
5\end{array}$ \\
$\mathrm{~T} 18$ & 154 & 0.03 & $<10$ & $<200$ & $\begin{array}{c}\text { Roof vent } \\
6\end{array}$ \\
$\mathrm{~T} 19$ & $<25$ & 0.03 & $<10$ & $<200$ & $\begin{array}{c}\text { Roof vent } \\
7\end{array}$ \\
$\mathrm{~T} 20$ & 320 & 0.03 & $<10$ & $<200$ & $\begin{array}{c}\text { Roof vent } \\
8\end{array}$ \\
$\mathrm{~T} 21$ & $<25$ & 0.02 & $<10$ & $<200$ & Roof vent \\
9
\end{tabular}

${ }^{a}$ Sample locations on the roof (T2-T8 and T16-T21) are shown on Fig. 17; indoor sample locations (T9-T15) are shown on Fig. 18.

${ }^{b}$ Instrument-specific minimum detectable activity (MDA) level $=25 \mathrm{dpm} / 100 \mathrm{~cm}^{2}$.

${ }^{c} \mathrm{MDA}=0.01 \mathrm{mrad} / \mathrm{h}$

${ }^{d}$ Removable radioactivity reported as net disintegration rates. Background radiation levels have been subtracted.

MDA $=10 \mathrm{dpm} / 100 \mathrm{~cm}^{2}$.

$f_{\mathrm{MDA}}=200 \mathrm{dpm} / 100 \mathrm{~cm}^{2}$. 


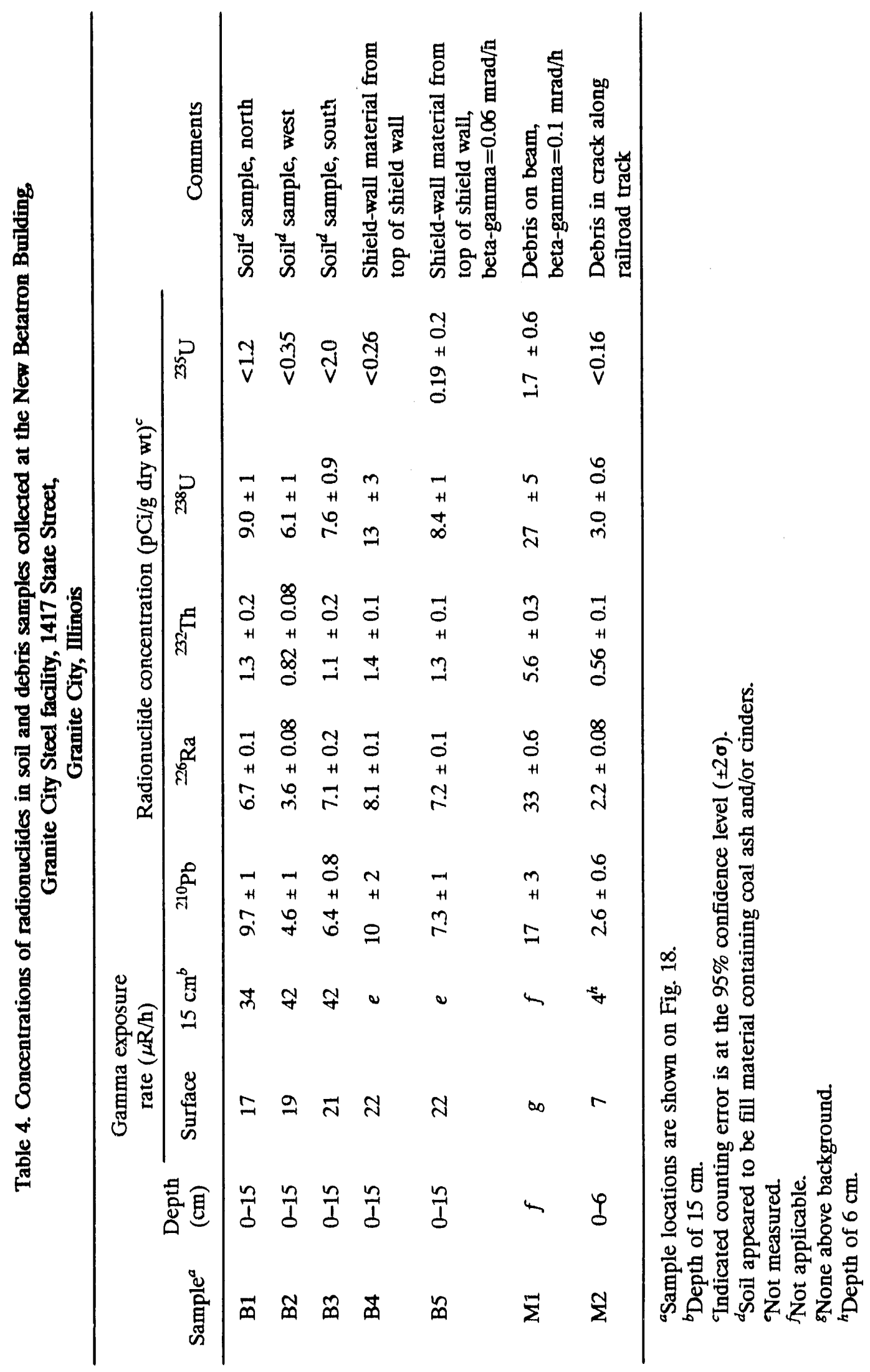


ORNL/RASA-91/8

\section{INTERNAL DISTRIBUTION}

1. B. A. Berven

2. R. F. Carricr

3-8. W. D. Cottrell

9. L. M. Floyd

10. R. D. Foley

11. C. A. Johnson

12. S. V. Kaye

13. A. P. Malinauskas

14-19. M. E. Murray

20. P. T. Owen

21. D. A. Roberts
22. R. E. Rodrigucz

23. P. S. Rohwer

24-26. R. E. Swaja

27-29. M. S. Uzicl

30. J. K. Williams

31-32. Laboratory Records

33. Laboratory Records - RC

34. Central Research Library

35. ORNL Technical Lib., Y-12

36. ORNL Patent Section

37-42. MAD Records Center

\section{EXTERNAL DISTRIBUTION}

43. J. D. Berger, Oak Ridge Associated Universities, E/SH Division, P.O. Box 117, Oak Ridge, TN 37831-0117

44. R. W. Doanc, TMA/Eberline, Inc., 795A Oak Ridge Turnpike, Oak Ridge, TN 37830

45. J. J. Fiore, U.S. Department of Energy, Office of Environmental Restoration and Waste Management, Decontamination and Decommissioning Division (EM-423), Washington, DC 20545

46-48. G. K. Hovey, Bechtel National, Inc., FUSRAP Department, P.O. Box 350, Oak Ridgc, TN 37831-(0350

49. L. K. Price, U.S. Department of Encrgy, Former Sites Restoration Division, DOE Field Office, Oak Ridge, P.O. Box 2001, Oak Ridge, TN 37831-8723

50. J. W. Wagoner, U.S. Department of Energy, Olfice of Environmental Restoration and Waste Management, Decontamination and Decommissioning Division (EM-423), Washington, DC 20545

51. W. A. Williams, U.S. Department of Energy, Oflice of Environmental Restoration and Waste Management, Decontamination and Decommissioning Division (EM-423), Washington, DC 20545

52. C. D. Young, Roy F. Weston, Inc., 1280) Middlebrook Road, Suite 207, Germantown, MD 20874

53. Office of Assistant Manager, Energy Research and Development, U.S. Department of Energy, DOE Field Office, Oak Ridge, P.O. Box 2001, Oak Ridge, TN $37831-8600$

54-56. Office of Scientific and Technical Information, DOE, P.O. Box 62, Oak Ridge, TN 37831 

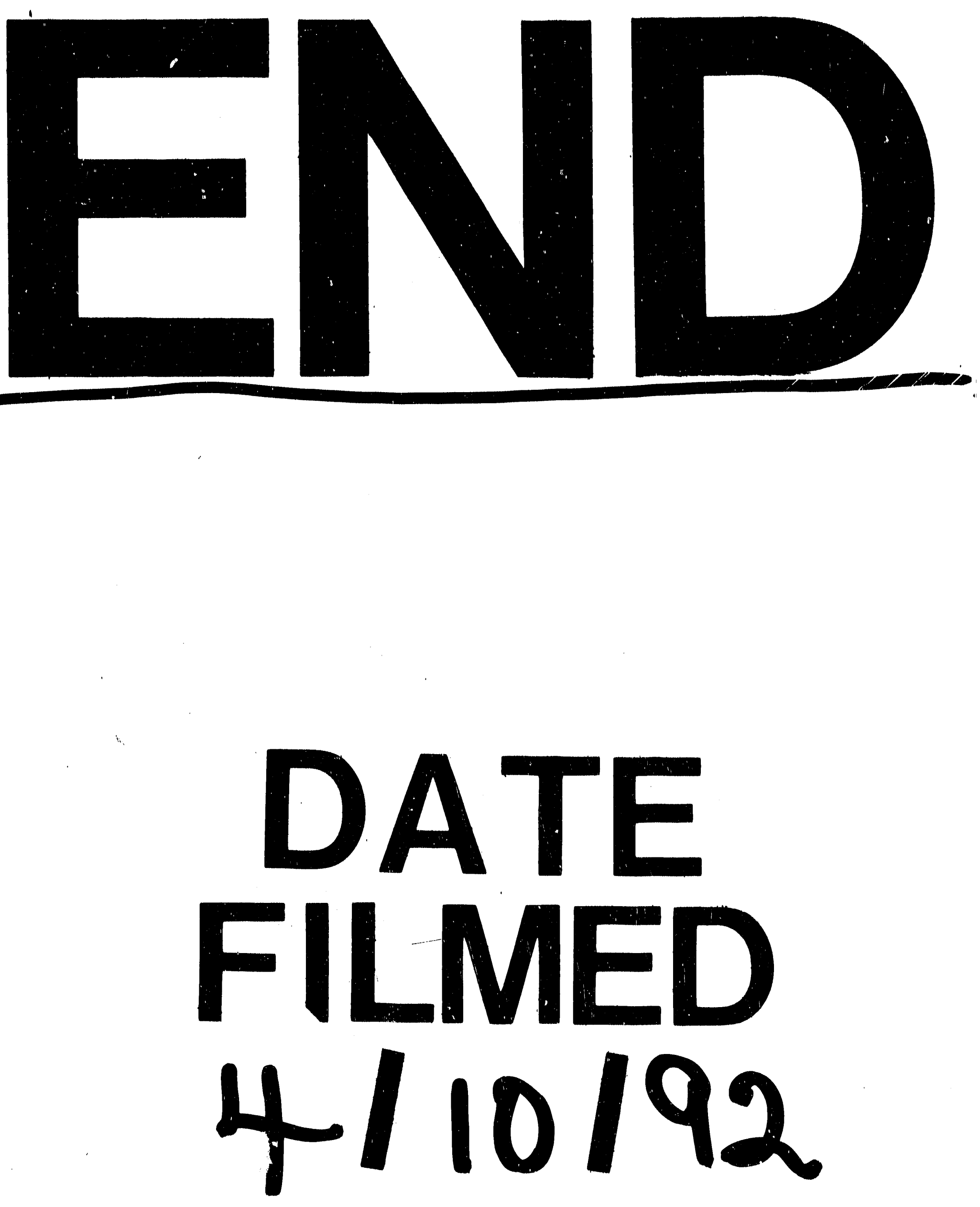


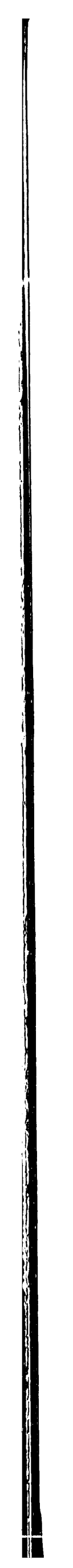

